A safety re-evaluation of the AVR pebble bed reactor operation and its consequences for future HTR concepts

Rainer Moormann 



\section{A safety re-evaluation of the AVR pebble bed reactor operation and its consequences for future HTR concepts}

Rainer Moormann 
Berichte des Forschungszentrums Jülich; 4275

ISSN 0944-2952

Forschungszentrum Jülich

Jül-4275

Vollständig frei verfügbar im Internet auf dem Jülicher Open Access Server (JUWEL) unter http://www.fz-juelich.de/zb/juwel

Zu beziehen durch: Forschungszentrum Jülich $\mathrm{GmbH} \cdot$ Zentralbibliothek, Verlag D-52425 Jülich · Bundesrepublik Deutschland

Z 02461 61-5220·Telefax: 02461 61-6103.E-Mail: zb-publikation@fz-juelich.de 


\section{Abstract}

The AVR pebble bed reactor (46 MW th) was operated 1967-88 at coolant outlet temperatures up to $990^{\circ} \mathrm{C}$. A principle difference of pebble bed HTRs as AVR to conventional reactors is the continuous movement of fuel element pebbles through the core which complicates thermohydraulic, nuclear and safety estimations. Also because of a lack of other experience AVR operation is still a relevant basis for future pebble bed HTRs and thus requires careful examination. This paper deals mainly with some insufficiently published unresolved safety problems of AVR operation and of pebble bed HTRs but skips the widely known advantageous features of pebble bed HTRs.

The AVR primary circuit is heavily contaminated with metallic fission products (Sr-90, Cs-137) which create problems in current dismantling. The amount of this contamination is not exactly known, but the evaluation of fission product deposition experiments indicates that the end of life contamination reached several percent of a single core inventory, which is some orders of magnitude more than precalculated and far more than in large LWRs. A major fraction of this contamination is bound on graphitic dust and thus partly mobile in depressurization accidents, which has to be considered in safety analyses of future reactors. A re-evaluation of the AVR contamination is performed here in order to quantify consequences for future HTRs (400 MW $W_{\text {th }}$ ). It leads to the conclusion that the AVR contamination was mainly caused by inadmissible high core temperatures, increasing fission product release rates, and not - as presumed in the past - by inadequate fuel quality only.

The high AVR core temperatures were detected not earlier than one year before final AVR shut-down, because a pebble bed core cannot yet be equipped with instruments. The maximum core temperatures are still unknown but were more than $200 \mathrm{~K}$ higher than calculated. Further, azimuthal temperature differences at the active core margin of up to 200 $K$ were observed, probably due to a power asymmetry. Unpredictable hot gas currents with temperatures $>1100^{\circ} \mathrm{C}$, which may have harmed the steam generator, were measured in the top reflector range.

After detection of the inadmissible core temperatures, the AVR hot gas temperatures were strongly reduced for safety reasons. Thus a safe and reliable AVR operation at high coolant temperatures, which is taken as a foundation of the pebble bed VHTR development in Generation IV, was not conform with reality. Despite of remarkable effort spent in this problem the high core temperatures, the power asymmetry and the hot gas currents are not yet understood. It remains uncertain whether convincing explanations can be found on basis of the poor AVR data and whether pebble bed specific effects are acting. Respective examinations are however ongoing. Reliable predictions of pebble bed temperatures are at present not yet possible.

The AVR contamination problems are related to the fact that even intact HTR fuel elements do not act as an almost complete barrier for metals, as they do for noble gases. Metals 
diffuse in fuel kernel, coatings and graphite and their break through takes place in long term normal operation, if fission product specific temperature limits are exceeded. This is an unresolved weak point of HTRs and is in contrast to other reactors: Intact LWR fuel elements represent a complete barrier despite of fuel centre temperatures of up to $2500^{\circ} \mathrm{C}$, because claddings remain at temperatures $<600^{\circ} \mathrm{C}$ which excludes release by diffusion. Another disadvantage of HTRs, responsible for the pronounced contamination, lies in the fact that activity released from fuel elements is distributed in HTRs all over the coolant circuit surfaces and on graphitic dust and accumulates there. Deposition rates of chemical reactive fission products in the HTR coolant circuit are large. Thus the removal of activity released from core by a coolant purging facility like in LWRs cannot be performed in gas cooled reactors.

Consequences of AVR experience on future reactors are discussed. For that, the influence of fuel quality on the AVR contamination is examined. In contrast to $\mathrm{Sr}$ and $\mathrm{Ag}$ the retention of Cs in intact coated particles of modern TRISO fuel, as present in AVR during its final years of operation, is even worse compared to former HTI-BISO fuel. On the other hand the fraction of defective fuel particles and of uranium outside particle kernels is smaller in modern fuel. Further, the retention of $\mathrm{Sr}$ in oxides kernels used in modern fuel is better than in former carbide kernels. For an AVR operation with only modern TRISO fuel the contamination is estimated to be by a factor of 10 to 30 lower for Sr-90. Smaller reductions are expected for $\mathrm{Cs}$ and $\mathrm{Ag}$. These results are not in conflict with recent high temperature irradiations of modern fuel, which discovered significant higher activity releases than expected.

As long as pebble bed immanent reasons for high core temperatures cannot be excluded they have to be conservatively considered in operation and design basis accidents of future pebble beds HTRs. For that case we have to note that AVR was operated for only less than 4 $y$ at hot gas temperatures $\geq 900^{\circ} \mathrm{C}$, and thus primary circuit contaminations in future reactors (400 MWth, $900^{\circ} \mathrm{C}$ hot gas temperature, modern fuel, 32 full power years) are expected to approach at least the same order as in AVR end of life. This creates problems: Former safety analyses for advanced small HTRs revealed that activities accumulated in the primary circuit are a major source term contributor in design basis accidents. Further maintenance and dismantling is significantly hindered. Another consequence of inadmissible high core temperatures to be considered in future reactors is the transgression of temperature limits, which prevent from formation of explosive gas mixtures in water ingress accidents of steam cycle and certain process heat generating designs. Ingress of liquid water into the pebble bed, as it accidently happened in AVR, has to be excluded in future reactors by design measures in order to avoid a potential positive void coefficient of reactivity with reactivity transients.

Criteria for the maximum tolerable accumulated activity in the coolant circuit are developed on basis of German regulations for protection of the public, i.e. maximum tolerable releases in design basis accidents, and of requirements from maintenance and disposal. Application 
of these criteria on advanced pebble bed reactors leads to the conclusion that a pebble bed HTR needs a gas tight containment even if inadmissible high temperatures as observed in AVR are not considered. However, a gas tight containment does not diminish the consequences of the primary circuit contamination on maintenance and dismantling. Inadmissible high temperatures substantially aggravate these problems. A safe operation at hot gas temperatures near to those suitable for process heat applications can currently not be guaranteed by pebble bed reactors, even if a gas tight containment is present.

Thus complementary measures to a containment in order to achieve safe operation of pebble bed reactors despite of activity accumulation in the primary circuit and of temperature uncertainties are discussed. A reduction of demands on future reactors (hot gas temperatures, fuel burn-up) is one option; another one is an elaborate $R \& D$ program for solution of the following problems related to operation and design basis accidents:

- development of a new fuel element sufficiently retaining metallic fission products in long term operation. For hot gas temperatures as in process heat applications the retention of non metallic fission products has to be improved, too

- development of a reliable quality control for fuel elements

- experiments on iodine release from fuel elements in core heat-up accidents

- full understanding and reliable modelling of core temperature behaviour and of pebble bed mechanics including pebble rupture

- fast and reliable local measurement (direct or indirect) of safety relevant parameters in the pebble bed core (e.g. temperatures)

- full understanding of fission product transport in the coolant circuit, including development of measures to avoid the current uncontrollable activity accumulation in the circuit

- development of a fast detection system for metallic fission product release from core

- material development for process heat components

- HTR specific dismantling and disposal items

A voluminously instrumented experimental pebble bed reactor would be required for solution of these problems. Before initiation of this comprehensive $R \& D$ a feasibility study including an estimate of the required effort is advisable in order to quantify the economical risk of this development. Comparative probabilistic safety assessments on pebble bed HTRs, HTRs with block type fuel and Generation III LWRs are proposed in order to generate a reliable figure of current pebble bed reactor safety: Former safety studies for pebble bed HTRs are expected to be too optimistic in light of improved knowledge. 


\section{Eine sicherheitstechnische Neubewertung des Betriebs des AVR-Kugelhaufenreaktors und Schlussfolgerungen für zukünftige Reaktoren}

\section{Zusammenfassung}

Der Kugelhaufenreaktor AVR (46 MWth) war von 1967-88 mit Kühlgasaustrittstemperaturen bis $990^{\circ} \mathrm{C}$ in Betrieb. Ein grundsätzlicher Unterschied von Kugelhaufen-HTR zu konventionellen Reaktoren liegt in der kontinuierlichen Bewegung von kugelförmigen Brennelementen durch das Core, was thermohydraulische, nukleare und sicherheitstechnische Berechnungen erschwert. Die Ergebnisse des AVR-Betriebs dienen als wichtige Grundlage der Entwicklung zukünftiger Kugelhaufenreaktoren, da es nur wenig andere belastbare Erfahrungen gibt. Daher müssen die AVR-Betriebserfahrungen sorgfältig analysiert werden. Diese Arbeit befasst sich vorwiegend mit einigen unzureichend veröffentlichten aber sicherheitstechnisch relevanten Problemen des AVR-Betriebes. Weithin bekannte Vorteile von Kugelhaufenreaktoren werden nicht behandelt.

Der AVR-Kühlkreislauf ist massiv mit metallischen Spaltprodukten (Sr-90, Cs-137) kontaminiert, was zu erheblichen Problemen beim gegenwärtigen Rückbau führt. Das Ausmaß der Kontamination ist zwar nicht exakt bekannt, aber die Auswertung von Spaltproduktablagerungsexperimenten lässt darauf schließen, dass diese Kontamination zum Betriebsende einige Prozent eines Coreinventars erreichte und damit um Größenordnungen über Vorausrechnungen und auch ganz erheblich über den Kontaminationen in großen LWR liegt. Ein bedeutender Anteil dieser Kontamination ist an Graphitstaub gebunden und damit in Druckentlastungsstörfällen teilweise mobil, was in Sicherheitsbewertungen zukünftiger Reaktoren zu berücksichtigen ist. In dieser Arbeit wird die AVR-Kontamination neu ausgewertet um Folgerungen für Projekte zukünftiger Kugelhaufen-HTR größerer Leistung zu quantifizieren. Dabei ergab sich, dass die Kontamination des AVR-Kühlkreislaufs nicht wie früher angenommen in erster Linie durch unzureichende Brennelementqualitäten verursacht wurde sondern durch unzulässig hohe Coretemperaturen, welche die Freisetzungen erheblich beschleunigten.

Die unzulässig hohen Coretemperaturen wurden erst 1 Jahr vor dem endgültigen AVRBetriebsende entdeckt, da ein Kugelhaufencore bisher nicht instrumentierbar ist. Die maximalen Coretemperaturen im AVR sind zwar weiterhin unbekannt, aber sie lagen mehr als $200 \mathrm{~K}$ über berechneten Werten. Außerdem wurden azimuthale Temperaturdifferenzen am Corerand von bis zu $200 \mathrm{~K}$ gemessen, welche vermutlich auf eine Leistungsschieflage zurückzuführen sind. Heißgassträhnen mit Temperaturen $>1100^{\circ} \mathrm{C}$, welche den Dampferzeuger geschädigt haben könnten, wurden gelegentlich oberhalb des Cores gemessen. 
Nach Entdeckung der unzulässig hohen Coretemperaturen wurden die Heißgastemperaturen aus Sicherheitsgründen drastisch abgesenkt. Eine sicheren und zuverlässigen AVR-Betrieb bei Prozesswärme-tauglichen Gasaustrittstemperaturen, wie er als Basis der KugelhaufenVHTR-Entwicklung im Generation IV Projekt unterstellt wird, hat es daher nicht gegeben. Obwohl erheblicher Aufwand in die Untersuchung der hohen Temperaturen, der Heißgassträhnen und der Leistungsschieflage investiert wurde sind deren Ursachen bisher nicht verstanden. Es bleibt unklar, ob eine eindeutige Erklärung auf der Basis der unzureichenden AVR-Daten überhaupt gefunden werden kann und ob Kugelhaufenspezifische Ursachen dominieren. Entsprechende Untersuchungen werden weitergeführt. Gegenwärtig sind zuverlässige Vorausrechnungen von Coretemperaturen im Kugelhaufen nicht möglich.

Die AVR-Kontaminationsprobleme hängen auch damit zusammen, dass intakte HTRBrennelemente nicht als fast vollständige Barriere für metallische Spaltprodukte angesehen werden können, wie sie es für Edelgase sind. Metalle diffundieren im Brennstofffkern, in den Beschichtungen und im Graphit. Ein Durchbruch durch diese Barrieren findet im LangzeitNormalbetrieb statt, wenn bestimmte, Spaltprodukt-spezifische Temperaturgrenzen überschritten werden. Hier liegt eine ungelöste Schwachstelle von HTR vor, die es bei anderen Reaktoren nicht gibt: Intakte LWR-Brennelemente stellen eine vollständige Spaltproduktbarriere trotz maximaler Brennstoffzentraltemperaturen von $2500^{\circ} \mathrm{C}$ dar, weil die Hüllrohre unter $600^{\circ} \mathrm{C}$ bleiben, was eine Freisetzung durch Diffusion ausschließt. Eine andere HTR-Schwachstelle, welche zu den AVR-Kontaminationen beigetragen hat, liegt darin begründet, dass sich die aus den Brennelementen freigesetzten Nuklide im HTR unkontrolliert über den gesamten Kühlkreislauf verteilen. Wegen der hohen Ablagerungsraten von chemisch reaktiven Spaltprodukten in HTR-Kühlkreisläufen kann nämlich die aus den Brennelementen freigesetzte Aktivität nicht über eine Reinigungsanlage entfernt werden, wie es im LWR Standard ist.

Schlussfolgerungen aus dem AVR-Betrieb für zukünftige Kugelhaufenreaktoren werden diskutiert. Dazu wird der Einfluss der Brennelementqualität auf die AVR-Kontamination untersucht: Im Unterschied zu Sr und Ag ist die Cs-Rückhaltung in intakten Partikeln moderner TRISO-Brennelemente, wie sie in den letzten Betriebsjahren im AVR vorhanden waren, schlechter verglichen mit den anfänglich benutzten HTI-BISO Brennelementen. Bei niedrigen Temperaturen wird das kompensiert durch die geringere Zahl defekter coated particles in TRISO-Brennelementen. Sr wird in modernen oxidischen Brennstoffkernen besser zurückgehalten als in den anfänglich verwendeten karbidischen Kernen. Unterstellt man, dass der AVR-Betrieb von Anfang an mit modernem TRISO Brennstoff erfolgt wäre, hätte sich eine um den Faktor 10 - 30 geringere Sr-Kontamination ergeben, aber die Reduktionsfaktoren für Cs und Ag wären geringer geblieben. Diese Abschätzungen stehen 
nicht in Widerspruch zu kürzlich durchgeführten Bestrahlungsexperimenten an modernen TRISO-Brennelementen bei hohen Temperaturen, welche erheblich höhere Freisetzungen als erwartet ergaben.

Solange Kugelhaufen-spezifische Ursachen für die erhöhten Coretemperaturen nicht ausgeschlossen werden können, müssen sie für Betrieb und Auslegungsstörfälle zukünftiger Reaktoren konservativ unterstellt werden. Dazu ist anzumerken, dass der AVR nur für insgesamt weniger als 4 Jahre bei Heißgastemperaturen $\geq 900^{\circ} \mathrm{C}$ betrieben wurde. Damit sind Kühlkreislaufkontaminationen moderner Reaktoren $\left(900^{\circ} \mathrm{C}\right.$ Kühlgastemperatur, 400 MWth, TRISO Brennstoff, 32 Vollastjahre) zu erwarten, die zu Betriebsende absolut gesehen mindestens in der gleichen Größenordnung wie beim AVR liegen. Daraus resultieren große Sicherheitsprobleme, weil - wie Sicherheitsstudien ausweisen - die im Kühlkreislauf akkumulierte Aktivität einen entscheidenden Beitrag zu Quelltermen von Auslegungstörfällen liefert und weil Wartung und Rückbau unzulässig behindert werden. Als weitere in zukünftigen Reaktoren zu berücksichtigende Folge unzulässig hoher Temperaturen ist die Überschreitung von Temperaturgrenzen zu nennen, oberhalb welcher brennbare Gasmischungen bei Wassereinbruchstörfällen auftreten. Dieses gilt jedoch nur für Anlagen mit Dampfkreislauf oder Prozesswärmeanlagen ohne Zwischenkreislauf. Bei Wassereinbrüchen muss zudem das Eindringen von flüssigem Wasser in den Kugelhaufen, wie es bei einem AVR-Störfall vorkam, konstruktiv ausgeschlossen werden um einen möglichen positiven Void-Koeffizienten der Reaktivität mit Reaktivitätsexkursion zu verhindern.

Kriterien für eine maximal tolerable akkumulierte Aktivität im HTR-Kühlkreislauf wurden auf der Basis deutscher Verordnungen für Auslegungsstörfälle sowie aufgrund von Anforderungen aus Wartung und Rückbau entwickelt. Die Anwendung dieser Kriterien auf Kugelhaufenreaktoren führt zum Schluss, dass ein gasdichtes Containment auch dann erforderlich ist, wenn keine überhöhten Coretemperaturen unterstellt werden. Durch ein gasdichtes Containment werden aber die mit Wartung und Rückbau zusammenhängenden Probleme nicht beeinflusst. Unzulässig hohe Coretemperaturen vergrößern diese Probleme erheblich. Ein sicherer Betrieb eines Kugelhaufenreaktors bei Temperaturen nahe denen für Prozesswärmenutzung erforderlichen ist damit gegenwärtig auch mit einem gasdichten Containment nicht zu garantieren.

Daher werden zusätzlich zu einem gasdichten Containment Maßnahmen diskutiert, um trotz der Unsicherheiten bei Coretemperaturen und der Akkumulation von Aktivität im HTRPrimärkreislauf einen sicheren Reaktorbetrieb zu gewährleisten. Eine Option besteht in der Verringerung der Anforderungen an zukünftige Reaktoren (Heißgastemperaturen, Brennstoffabbrand), eine andere ist ein sehr umfangreiches F+E-Pogramm zur Lösung der nachstehend aufgeführten Probleme im Normalbetrieb und bei Auslegungsstörfällen: 
- Entwicklung eines neuen Brennelementes, welches metallische Spaltprodukte im Langzeitbetrieb hinreichend zurückhält. Für Prozesswärmeanwendungen muss auch die Rückhaltung nichtmetallischer Spaltprodukte verbessert werden

- Entwicklung einer zuverlässigen Qualitätskontrolle für Brennelemente

- Experimente zur Jodfreisetzung aus Brennelementen für Bedingungen von Coreaufheizstörfällen

- Zuverlässige Modellierbarkeit der HTR-Temperaturen und der Kugelhaufenmechanik einschließlich von Kugelbruchvorgängen und deren Auswirkungen

- Schnelle und zuverlässige lokale Messung (direkt oder indirekt) von sicherheitsrelevanten Parametern wie Temperaturen im Kugelhaufencore

- Zuverlässige Modellierbarkeit des Spaltprodukttransportes im Kühlkreislauf, Entwicklung von Methoden zur Verhinderung der unkontrollierbaren Spaltproduktakkumulation im Kreislauf

- Entwicklung eines schnellen Verfahrens zur Messung der Freisetzung von metallischen Spaltprodukten

- Materialentwicklung für Prozesswärmekomponenten

- HTR-spezifische Rückbau- und Endlagerungsprobleme

Ein umfangreich instrumentierter experimenteller Kugelhaufenreaktor wäre zur Lösung dieser Probleme unverzichtbar. Bevor ein F+E-Programm dieser Größe begonnen wird sollte eine Machbarkeitsstudie einschließlich Aufwandsabschätzung durchgeführt werden, um das ökonomische Risiko dieser Entwicklung zu quantifizieren.

In Hinblick auf auslegungsüberschreitende Störfälle sind Sicherheitsprobleme bei Lufteinbruch/Corebrand noch nicht hinreichend gelöst. Eine vergleichende Sicherheitsstudie von Kugelhaufen-HTR, Block-HTR und Generation-III LWR wäre hilfreich, um eine zuverlässigere Aussage zur Sicherheit gegenwärtiger Kugelhaufen-HTR-Konzepte zu bekommen: Frühere Sicherheitsstudien für Kugelhaufenreaktoren müssen aus heutiger Sicht als zu optimistisch angesehen werden. 


\section{CONTENT}

1. INTRODUCTION

2. AVR CORE TEMPERATURES 3

2.1 Measurement technique and results 3

2.2 Interpretations of unintentional high temperatures $\quad 5$

3. RE-EVALUATION OF FISSION PRODUCT RELEASE FROM AVR CORE INTO THE COOLANT CIRCUIT $\quad 8$

$\begin{array}{lr}\text { 3.1 Release data } & 8\end{array}$

3.2 Influence of unintentional temperatures on fission product release 11

3.3 Release mechanisms of metallic fission products 12

3.4 Interpretation of AVR release rates after hot gas temperature increase to $950^{\circ} \mathrm{C}$

3.5 Dependence of activity release from AVR core on the core composition 17

3.6 Comparison of HTR and LWR fission product behaviour 23

4. RELEVANCE OF AVR EXPERIENCE FOR FUTURE PEBBLE BED REACTORS

4.1 Maximum permissible environmental release in design basis accidents 24

4.2 Consequences of AVR experience for water ingress accidents 29

4.3 Consequences of AVR experience for core heat-up accidents 30

5. CONCLUSION 30

$\begin{array}{ll}\text { ACKNOWLEDGEMENT } & 33\end{array}$

$\begin{array}{ll}\text { REFERENCES } & 34\end{array}$ 


\section{Introduction}

The AVR was the first pebble bed HTR worldwide and was operated 1967-88 in Juelich. Main aim of this experimental reactor was the principal test of the pebble bed core and test of many different types of pebble shaped fuel elements. Design data of the AVR $[1,3]$ are collected in table I. A sketch of the reactor and of some relevant components is presented in fig. 1. AVR was equipped with a double wall pressure vessel and with a gas tight containment, in order to compensate the wrong fuel quality (no coated fuel particles) in the AVR design period. However at operation start the meanwhile developed better retaining coated particle fuel element was used. Containment and double wall pressure vessel were however not able to withstand certain sequences of water ingress accidents by tube rupture in the steam generator. Water ingress accidents became therefore design basis accidents in AVR.

The AVR pebble bed core consists of about 100000 graphite pebbles, which each contain in their centre part usually about 10000 to 40000 multicoated fuel particles. Diverse fuel types with different coatings were used (see [3], p. 313). Except of GLE-1 type (see chapter 3.4) all fuel pebbles contained $1 \mathrm{~g} \mathrm{U}-235$, but the total heavy metal content varied from 6 to $11 \mathrm{~g}$. After a residence time of $4-40$ (average $6-8$ ) months in the core the fuel elements reach the defueling tube at the core bottom and are re-fed to the core top. This is repeated until the final burn-up is met and then the fuel element is replaced by a fresh one. In order to achieve a radial more even temperature profile low power fuel elements are fed into the core centre and fresh ones into the outer regions. Pebble flow velocities are higher in the inner than in the outer core region. Helium cools the core in up flow direction. A steam generator is arranged in the top of the pressure vessel.

\begin{tabular}{|l|l|}
\hline $\begin{array}{l}\text { Power / Average power } \\
\text { density }\end{array}$ & $46 \mathrm{MW}_{\text {th }}\left(15 \mathrm{MW}_{\mathrm{el}}\right) / 2.5 \mathrm{MW} / \mathrm{m}^{3}$ \\
\hline Cycle & $\begin{array}{l}\text { Steam cycle with the steam generator (73 bar) inside } \\
\text { the reactor vessel }\end{array}$ \\
\hline Core height / diameter & $2.8 \mathrm{~m} / 3 \mathrm{~m}$ \\
\hline Coolant / Pressure & $\mathrm{He} / 10.8 \mathrm{bar}$ \\
\hline He outlet / inlet temperature & $\begin{array}{l}1^{\text {st }} \text { phase until } 02 / 1974: \leq 850^{\circ} \mathrm{C} ; 2^{\text {nd }} \text { phase from } \\
02 / 1974: \leq 50(990)^{\circ} \mathrm{C} / 275^{\circ} \mathrm{C}\end{array}$ \\
\hline He-flow & $\begin{array}{l}13-15.5 \mathrm{~kg} / \mathrm{s} \text { (depending on desired gas outlet } \\
\text { temperature) in up flow direction }\end{array}$ \\
\hline Fuel & $\begin{array}{l}\text { Core: } 100000 \text { matrix graphite pebbles }(6 \mathrm{~cm} \text { diam.) } \\
\text { containing coated fuel particles. Diverse fuel types, at } \\
\text { end mainly improved TRISO fuel }\end{array}$ \\
\hline
\end{tabular}

Table I: Main design data of AVR pebble bed reactor 

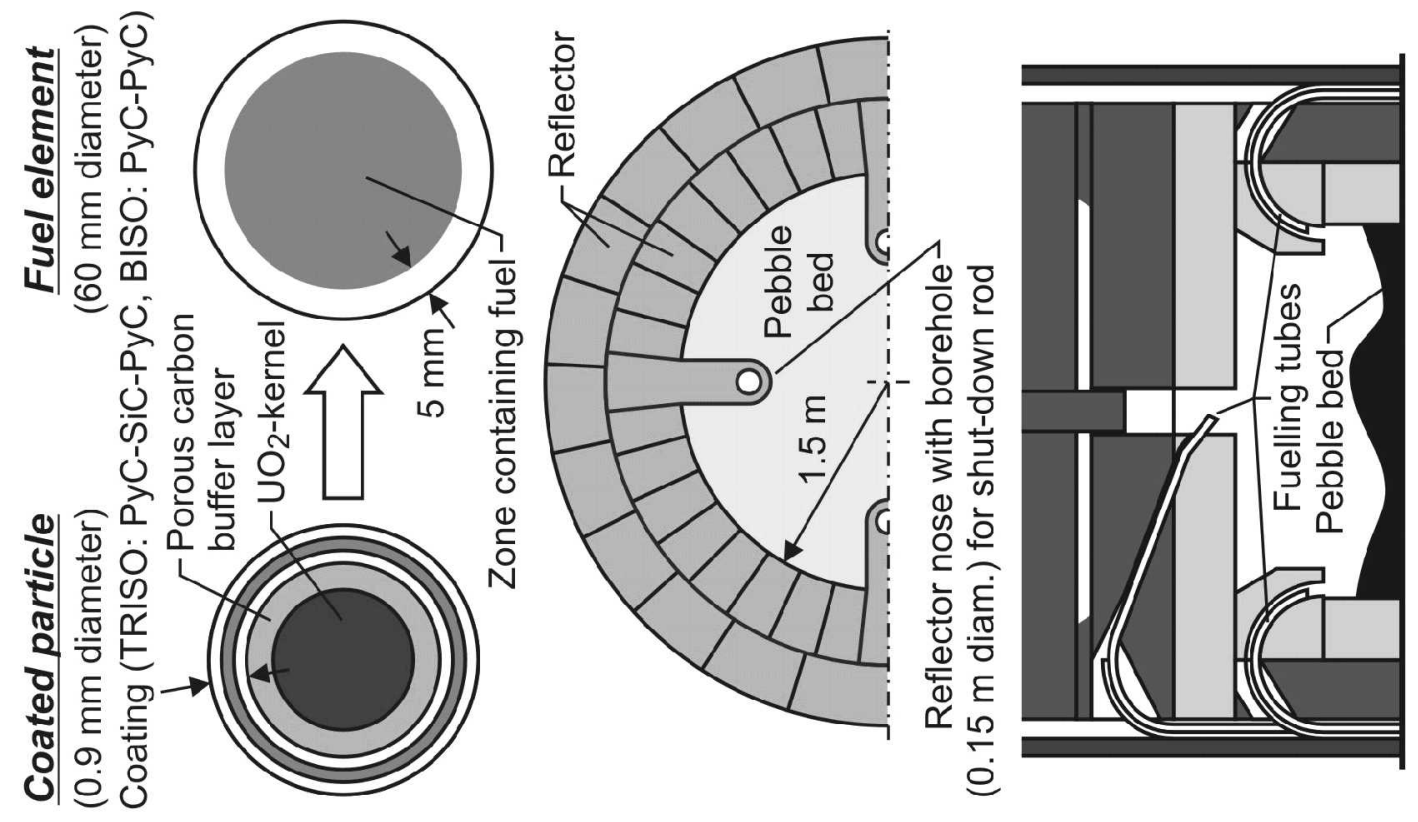

2
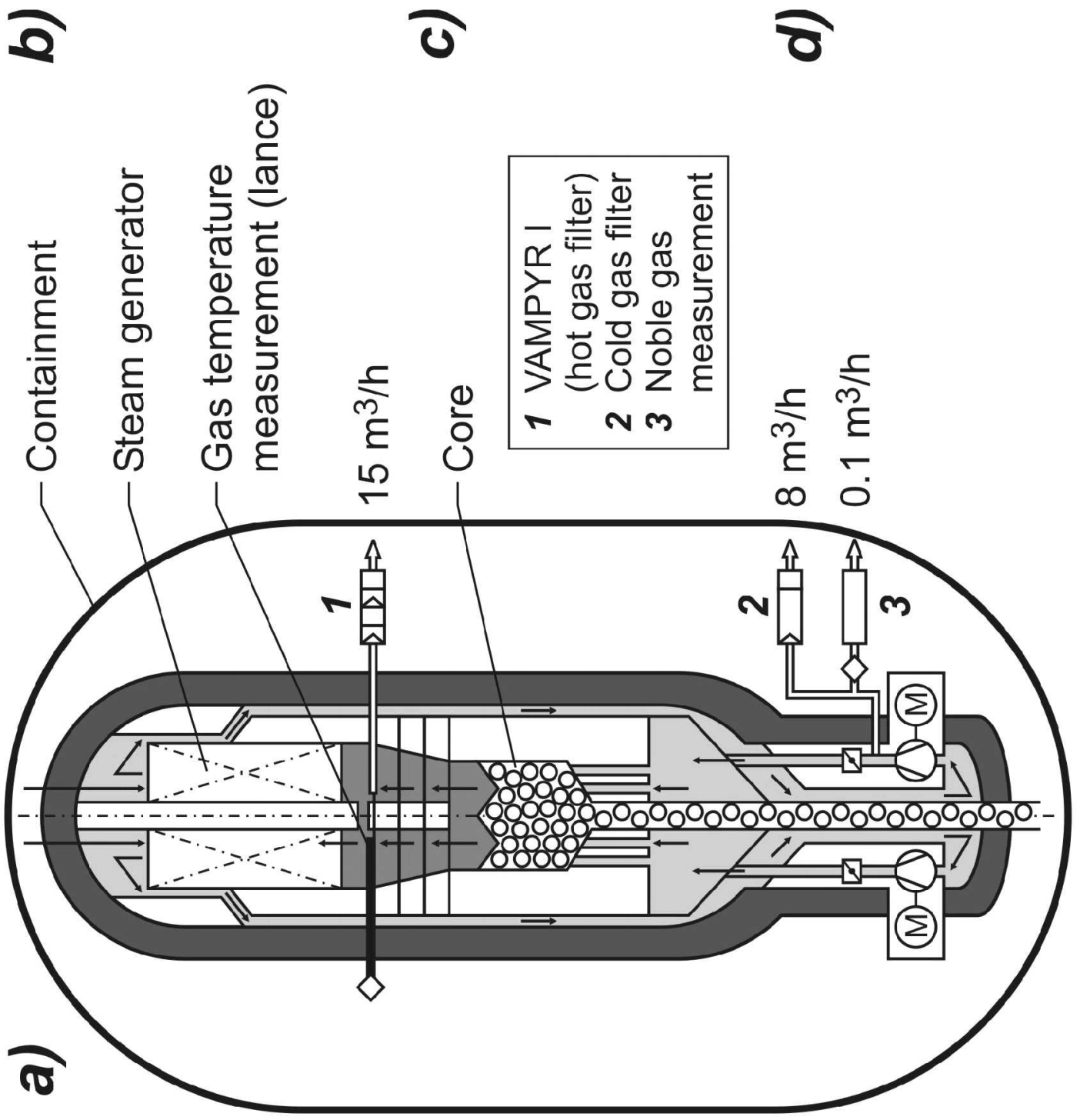

Fig. 1: Scheme of the AVR (a) with fuel element (b), view on core from top (c) and fuelling facilities 
Although several improvements are foreseen for future pebble bed reactors AVR is in many respect still their paragon, also because the larger demonstration reactor THTR (750 MWth) suffered from diverse problems and was operated thus only for less than 1.5 full power years. R\&D on pebble bed reactors was limited since the end of AVR operation and thus its experience is still of major relevance. Particularly because hot gas temperatures of up to almost $1000^{\circ} \mathrm{C}$ were achieved in AVR, which allow for process heat applications, the pebble bed technology finds major interest worldwide. This paper focuses on some unresolved and insufficiently published safety relevant problems which occurred during AVR operation, and outlines consequences for future pebble reactor concepts. The widely published advantageous features $[1,44]$ of pebble bed HTRs are out of the scope of this paper.

At the moment AVR undergoes dismantling, which became complicated due to a pronounced contamination of the primary circuit with Sr-90 and Cs-137. Particularly highly radiotoxic Sr90 creates safety concern because this contamination is partly present in mobile, dust borne form. Accordingly, the reactor vessel will be grouted with light concrete which immobilizes dust and stabilizes the vessel, and will be stored for some decades outside of the AVR site, until a procedure for final dismantling is developed. A re-evaluation of the heavy primary circuit contamination is performed in this paper. Besides the standard explanation that an insufficient fuel quality was primarily responsible for that [1a], also other reasons like overheating of fuel elements by inadmissible high core temperatures, as detected at the end of AVR operation, will be examined. Further other safety relevant experience from AVR operation will be discussed and conclusions for future reactors will be drawn.

\section{AVR core temperatures}

\subsection{Measurement technique and results}

There is no way of a contemporary measurement of active core temperatures in pebble bed HTRs, in contrast to other reactors, because the pebble movement destroys all standard detection equipments. Hot gas temperature profiles outside of the active core were measured occasionally in AVR [20, 40], but core temperatures were based for most of the AVR operation time on calculations only. For average AVR hot gas temperatures of $950^{\circ} \mathrm{C}$ maximum surface temperatures of fuel elements were originally calculated to $1070^{\circ} \mathrm{C}$ [2]. Depending on the fission power of the respective fuel element, maximum coated particle temperatures are up to $120 \mathrm{~K}$ higher. Modern fuel elements were designed for a maximum coated particle temperature in long term normal operation of $\leq 1250^{\circ} \mathrm{C}$. However sufficient irradiation tests were until recently (see chapter 3.3) available only for lower temperatures or low burn-up [48]. This is because irradiations concentrated on the less stringent conditions of the HTR-Module200 (see chapter 4.1). 
In this paper, the term core temperature means fuel element surface temperature. A crude method for measurement of maximum core temperatures in pebble bed HTRs was developed already 1970 to $1972[8,30]$. Limited tests were performed for the less problematic inner core region only, but revealed temperatures of up to about $100 \mathrm{~K}$ higher than calculated at hot gas temperatures of $750^{\circ} \mathrm{C}$ and $850^{\circ} \mathrm{C}$. There was however an alteration of the feeding rate into the inner core from 1971 to 1981 (see chapter 3.5), which complicates a comparison to other operation periods. An improved technique was applied from September, 1986 [1b,3]: 190 graphite pebbles equipped with 20 melt wires (melting points from $650-1280^{\circ} \mathrm{C}$ ) were fed onto the core top. Following precalculations, all monitor pebbles passed the hottest part of the core within of about one month, and in this period the AVR hot gas temperature was hold at $950^{\circ} \mathrm{C}$. The monitor pebbles detected the maximum gas temperature a pebble passes through during its flow through the core, plus some minor contribution by $\gamma$ and neutron heating of $8 \pm 2 \mathrm{~K}$ [8]. For the hot core top the maximum gas temperature was calculated to be $30 \pm 10 \mathrm{~K}$ below the adjacent fuel element surface temperature, see Collection of Reactor Physics Data 1983 in [25]. This together means that maximum core temperatures are about $22 \pm 12 \mathrm{~K}$ higher than maximum temperatures measured by monitor pebbles.

\begin{tabular}{|c|c|c|}
\hline $\begin{array}{c}\text { Range of } \\
\text { maximum } \\
\text { temperature } \\
\text { [ } \mathrm{C} \text { ] }\end{array}$ & $\begin{array}{c}\text { Percentage of monitor pebbles belonging to the given range of } \\
\text { maximum temperatures, separated for monitor pebbles fed onto } \\
\text { radial inner core [\%] } \\
\text { radial outer core [\%] }\end{array}$ \\
\hline $920-1072$ & $35\left(25>1050^{\circ} \mathrm{C}\right)$ & 0 \\
\hline $1073-1280$ & 58 & 69 \\
\hline$>1280$ & 7 & 31 \\
\hline
\end{tabular}

Table II: Maximum gas temperatures in the AVR active core during normal operation as measured by monitor pebbles (starting 09/1986). Corresponding core (fuel element surface) temperatures are about $20 \mathrm{~K}$ higher.

The temperature results are summarized in table II. More detailed data on temperatures and insertion of monitor pebbles are found in [50,54]. 144 monitor pebbles left the core until mid $1988[1 b, 3]$. The not evaluated 46 pebbles belong mainly to the outer core region, which may be explained by a smaller pebble flow rate adjacent to the wall. Except of about $1 / 3$ of the pebbles fed into the radial inner core zone, all pebbles revealed higher temperatures than the maximum of $1070^{\circ} \mathrm{C}$, originally calculated for licensing of the operation at hot gas temperatures of $950^{\circ} \mathrm{C}$ [2], $1 / 3$ of the pebbles fed into the radial outer zone even by more than $200 \mathrm{~K}$. Precalculations with improved codes of maximum central temperatures of monitor pebbles for the temperature measurement campaign resulted in values of $1123^{\circ} \mathrm{C}$ for the outer core and $1051^{\circ} \mathrm{C}$ for the inner core [30]. In line with that later temperature calculations revealed for certain AVR core compositions maximum core temperatures as high 
as $1140^{\circ} \mathrm{C}$. This however holds for a limited time and for a small volume fraction of the core of less than $1 \%$ at temperatures greater than $1100^{\circ} \mathrm{C}$ only. Accordingly, the deviations to measurements remain large. Postexaminations on monitor pebbles were performed in order to exclude that errors, e.g. mixing of melt wire positions, may have occurred [51]. The influences of a reactor shut down beginning of November, 1986 on measured temperatures was examined, too and found to be negligible [51].

Gaseous [1a] and metallic (see fig. 3) fission product release was normal or even small during the temperature measurement campaign. This indicates that the temperature elevations did not occur during the campaign only, but in whole AVR operation.

The absolute maximum temperature was not measured, because it was higher than the highest melting point of the melt wires used. True maximum core temperatures in the inner respectively outer core are coarsely assessed to 1320 to $1340^{\circ} \mathrm{C}$ respectively 1380 to $1420^{\circ} \mathrm{C}$. The differences between inner and outer core reflect the fact that low power (high burn-up) fuel was mainly fed into the inner core. The volume fraction of the outer core zone is larger than that of the inner one, but varied with AVR fuelling. On the other hand, the throughput in the inner core was larger.

When first temperature results became available the permit for AVR operation at $950^{\circ} \mathrm{C}$ hot gas temperature was withdrawn for safety reasons and the hot gas temperature had to be strongly reduced from beginning of 1988 ([3], p.190). This temperature drop is seen in fig. 2. For that there was no possibility to repeat the measurement of absolute maximum core temperatures with melt wires of higher melting points. Altogether, the AVR should no longer be taken as reference for a safe and reliable reactor operation at gas temperatures allowing process heat applications, as is e.g. done as foundation of pebble bed VHTR development in the context of Generation IV [35].

Ironically, the pebble bed HTR concept has probably survived until now only as consequence of one of his weak points, its insufficient in-core instrumentation abilities: In case of known AVR core temperatures from beginning of its operation, the AVR hot gas temperatures would have been limited to values far below $950^{\circ} \mathrm{C}$. This means that its main advantage, its apparent capability for process heat generation, would not have been demonstrated.

\subsection{Interpretations of unintentional high temperatures}

The reasons for the high AVR core temperatures could not be clarified up to now $[9,39]$. It is not even completely clear, whether there were several hot spots of limited volume in the core or even large regions of high temperatures. However, the pronounced fission product release discussed in chapter 3 suggests a large fraction of fuel elements with inadmissible high temperatures in the AVR core. Several AVR specific but also pebble bed immanent and general reasons and their combinations are in discussion (coolant bypass flows inside and/or outside of the active core, power peaks near to AVR reflector noses, uncertainties in pebble 
bed stochastics, locally densified pebble bed with high flow resistance, human errors in fuelling procedure, uncertainties in pebble flow behaviour, uncertain burn-up measurements particularly until 1981, power asymmetry in the core, cones of pebbles on the core top, flow anomalies by the broken AVR bottom reflector [18] etc.). Detailed examinations were performed up to now, but only for AVR specific and general, but not sufficiently for pebble bed immanent reasons. Complicating it was found that some effects compensate others, e.g. bypasses cool down regions with elevated nuclear heating.

The sophisticated fuelling procedure in AVR as described in chapter 1 contributes to these uncertainties: The fuel element feeding frequency at different positions was varied several times. Unfortunately, the fuelling was not performed in a sufficiently radial symmetric manner, as was discovered in 1985. In detail, the feeding foreseen to the centre axis occurred with a shift of $0.5 \mathrm{~m}$ to one side (see fig. $1 \mathrm{~d}$ ). This leads to still more complicated pebble flow and may have been one reason of the azimuthal power asymmetry. Altogether, pebble flow behaviour, whose detailed knowledge is essential for neutronics and thermohydraulic calculations, was never completely understood during AVR operation: Deviations between calculated and observed residence time spectra of fuel elements in the inner core reached up to about $30 \%$ even at the end of AVR operation. This means that the spatial distribution of fissiles in the core was not exactly known. One reason for these discrepancies is the small experimental basis of pebble flow dynamics in HTR pebble beds: The basic experiment on flow of individual pebbles in beds was performed with glass pebbles in an organic liquid [1c]. Although this experiment was obviously far away from conditions in pebble bed reactors, its qualitative results are assumed to be valid for pebble bed HTRs. Also, all experiments on graphite pebble beds, giving information about residence time spectra, were unfortunately performed under non representative friction conditions: The friction of graphite is strongly reduced in presence of a chemisorbed oxygen layer, which was present in all experiments. Such a layer is instantaneously formed in ambient atmosphere, but is destroyed at HTR operation temperatures in Helium. Accordingly, the friction in all simulation experiments using graphite pebbles was much smaller than in real HTR pebble beds. This became obvious after several years of AVR and THTR operation by very strong deviations between measured and predicted residence time spectra of fuel elements in the core.

3D computer simulation revealed [12] that around reflector noses temperatures are higher by up to $80 \mathrm{~K}$ due to neutronics effects, i.e. this may explain only part of the observed temperature enhancement. Similar holds for other AVR specific reasons [20], as bypasses inside and outside of the active core. Temperature measurements by monitor pebbles in the inner core during an AVR experiment (loss of coolant accident simulation) [13] did not show deviations from calculated maximum temperatures: In this experiment there was no forced flow, but nuclear heating for simulation of the decay heat. This may be taken as an indication, 
that flow plays a major role as reason for high temperatures. Temperatures in reflector noses measured in 1988 revealed remarkable azimuthal differences of up to $200 \mathrm{~K}$ at full power operation and hot gas temperatures of about $750^{\circ} \mathrm{C}$. These azimuthal temperature differences decreased only to $140 \mathrm{~K}$, when blowers were stopped but nuclear heating remained at $4 \mathrm{MW}$. This points to the before mentioned power asymmetry, as $3 \mathrm{D}$ thermo/fluiddynamic calculations indicated [32].

At present some effort is spent in clarification of the inadmissible AVR-temperatures by advanced codes, as operated by PBMR: Particularly a combination of several AVR specific reasons is under examination, but pebble bed immanent reasons as pebble bed densifications afford major attention, too: A statistically generated pebble bed has a void fraction of about 0.4 , and this is assumed for HTR pebble beds in average. Achievable minimum void fractions in pebble beds are however as low as $\mathbf{0 . 2 6}$. Regions with low void fractions show substantially higher temperatures mainly because of their strongly enlarged pressure drop, i.e. reduced cooling, but also because of an enlarged power density. The temperature increase by densification depends on the size of the densified region: Several hundred $\mathrm{K}$ are expected for densified regions of some thousand pebbles. During AVR construction it became obvious, that movement of pebble beds leads to pronounced pebble bed densifications, because the densest pebble bed represents the equilibrium state. In order to avoid densification indentations were worked into the AVR side reflector surface. Experiments on beds of small metal pebbles at room temperature in air showed that this measure prevents from major pebble bed densifications for the whole experimental bed [1c]. It remains however unclear, whether the latter result is representative for real HTR pebble beds with their large friction and high temperatures: It remains to be shown, that HTR pebble bed densifications can be excluded also in some distance from the reflector surface. A remarkable increase of pebble bed densities was observed in THTR, whose reasons are controversially discussed.

Clustering of low burn-up, high power fuel elements in the core have also to be considered as reason of high temperature regions.

A complete 3D simulation of AVR thermohydraulics, neutronics and pebble bed mechanics is currently undertaken to resolve the problem. However the data situation in AVR concerning core temperatures, power distribution etc. is very poor also due to the lack of in-core instrumentation. For that and because of complicated pebble bed mechanics and fuelling there are doubts, whether one single explanation can be found and whether pebble bed immanent reasons as partial densification of the pebble bed or clusters of high power fuel elements can be excluded. Probably, only a future operation of a representative large scale experiment or of an experimental pebble bed reactor can convincingly answer the remaining questions. 
Experience of the THTR pebble bed reactor also gives hints to enhanced temperatures: Failure of insulation attachment bolts in the hot gas duct was probably caused by thermal fatigue due to excessive temperature gradients across the core outlet. One explanation is that debris of broken pebbles has strongly diminished the pebble flow velocity in the outer core zone compared to the inner region, which changed the radial power distribution. Reduced flow velocities of fuel elements in pebble beds may lead to inadmissible high burnup and accelerated fission product release. In an annular pebble bed core with a centre graphite column the pebble bed surfaces contacting reflectors are particularly large and accordingly, the regions with delayed pebble flow, too.

\section{Re-evaluation of fission product release from AVR core into the coolant circuit}

\subsection{Release data}

Measurements of $\mathrm{Cs}, \mathrm{Sr}$ and $\mathrm{Ag}$ release from AVR core by a deposition tube in the hot gas region (VAMPYR-I, see fig. 1) revealed, that the fission product release into the primary circuit strongly accelerated 1974 - 1976, correlating with the hot gas temperature increase from 850 to $950^{\circ} \mathrm{C}$ in February, 1974. Time dependent accumulated release values mainly based on measurements in VAMPYR-I and corresponding average hot gas temperatures are shown in figure 2. Specific Cs-137 coolant activities are shown in fig. 3.

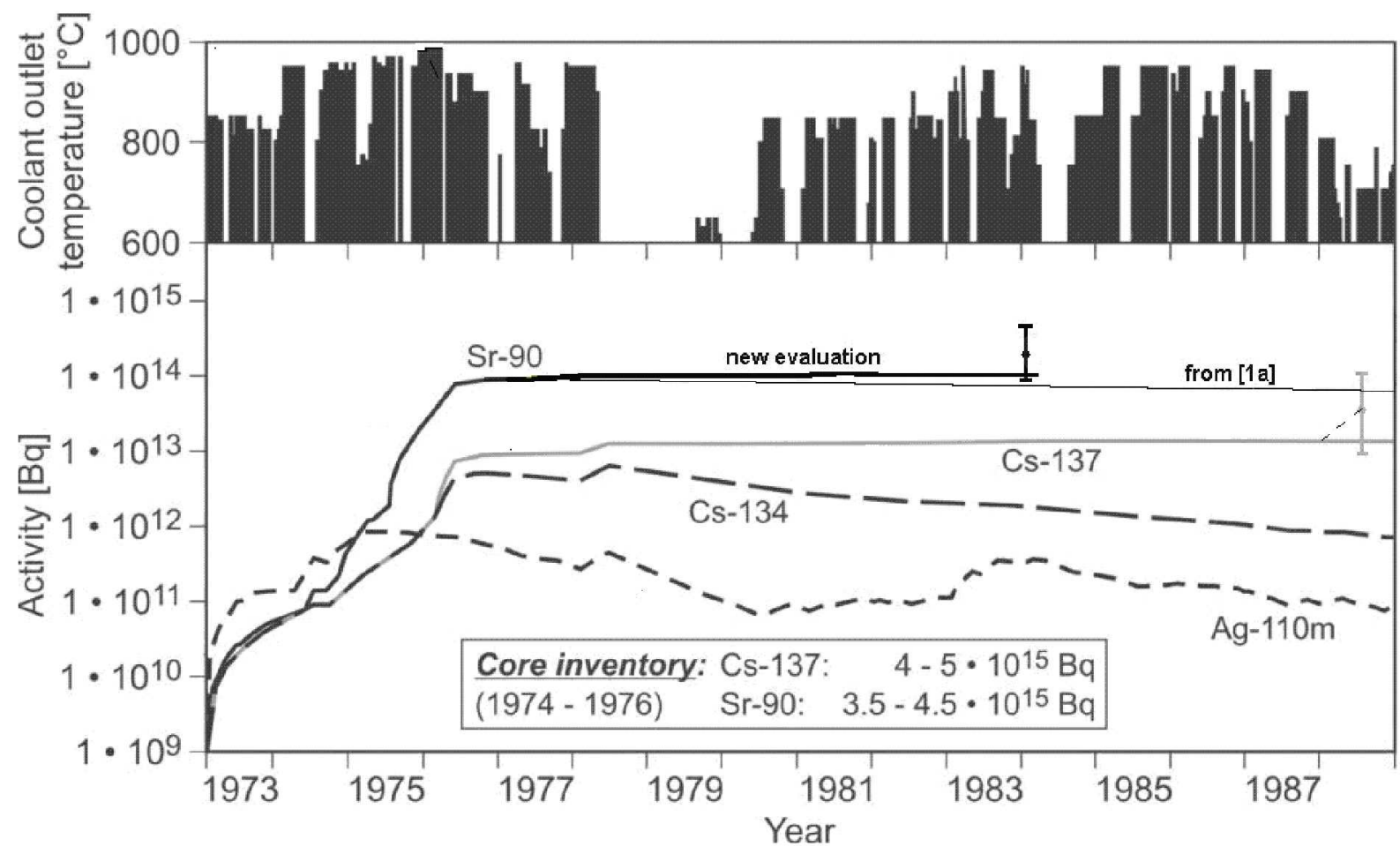

Fig. 2: Time dependent average hot gas temperatures (above) and accumulated activity release into the AVR primary circuit estimated from VAMPYR-I hot gas filter results for Cs-137 and Sr-90 with uncertainty scatter (below). Core inventories are from [49]. 
These specific coolant activities are approximately proportional to the core release rate. Time dependent accumulated releases for $\mathrm{Cs}$ in a linear scaling are presented in fig. 7. Data of fig. 2 are taken from [1a] except the Sr-90 branch labelled as 'new evaluation'. In a revaluation Sr-90 estimations of [1a] were found to be not consistent with VAMPYR-I results and too low: For operational safety and cost reasons Sr-90 measurements in VAMPYR-I were abandoned mid of 1974 and were replaced by Eu-154 measurements, considering that Eu-154 shows a similar release behaviour as Sr-90. However for generation of Sr-values in [1a] Sr-90 and Sr89 data of the AVR cold gas region (cold gas filter) were used for the period until mid of 1976. From mid of $1976 \mathrm{Sr}-90$ data from the cold gas filter led to inconsistent release rates because of continuous Sr-90 accumulation in the dust (see chapter 3.4). For that solely Sr-89 results of the cold gas filter were considered in [1a] from end of 1976, assuming that there is no substantial diffusion induced delay of the core release. However, as seen from fig. 2 and discussed in chapters 3.4 and 3.3 the diffusion induced delay is about by a factor 5 larger than the halve life of $\mathrm{Sr}-89(50 \mathrm{~d})$. This means that the method applied in [1a] underestimated Sr-90 release rates from 1977 by a factor of $10-50$. Thus the conclusion from [1a] that after 1977 only a negligible Sr-90 release took place and a continuous declination of the Sr-90 activity occurred by radioactive decay is too optimistic. Eu-154 release rates measured in VAMPYR-I guide in the same direction: For June - September 1984 the relative Eu-154 release rates are by a factor of 20 larger than relative $\mathrm{Sr}-90$ release rates as assumed in [1a]. A re-estimation of Sr-90 release rates based on Eu-154 measurements in VAMPYR-I, which are available for 1974 - 1984, is shown as bold line in fig. 2, too. Activities in 1984 became about a factor of 1.2 larger than assumed in [1a]. This reflects that the Sr-release did not stop in 1976 as erroneously assumed in [1a] but continued.

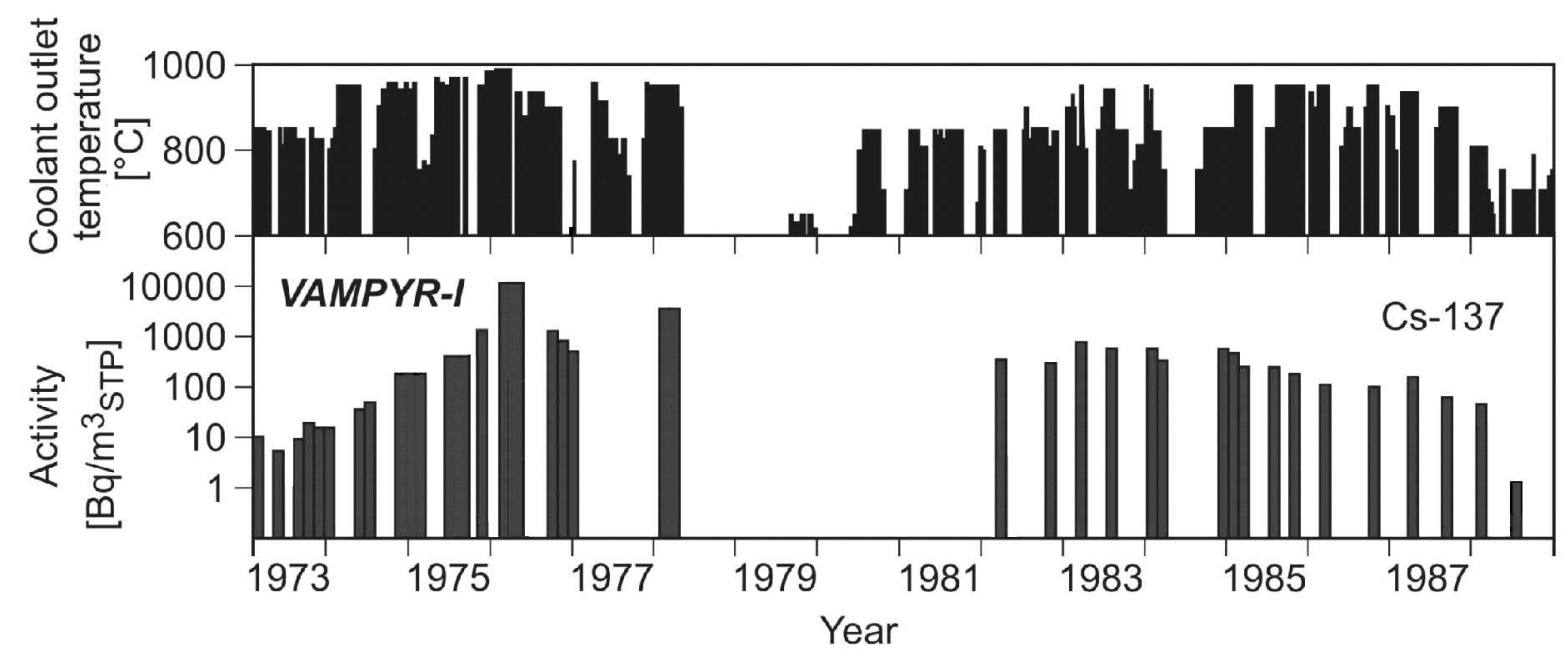

Fig.3: Specific Cs-137 activities in hot gas as measured in VAMPYR-I depending on average hot gas temperatures. VAMPYR-I coolant activities are known to be too low by a factor of 5 to 10 .

It is supposed that the time dependence of the releases in fig. 2 and 4 is approximately correct, although the absolute values are now known to be too low. This was probably due to 
insufficient mixing of hot gas at the gas inlet of VAMPYR-I: A pronounced azimuthal and radial hot gas temperature gradient existed in AVR at the niveau of VAMPYR-I [20]: Release rates measured in VAMPYR-I are not representative for the whole core, but preferently for some cooler outer core regions [24]. This is probably due to bypass flows streaming into direction of VAMPYR-I and - looking on the power asymmetry - to the position of VAMPYR-I in a azimuthal core region with low temperatures. This underestimation becomes also obvious, if release rates measured in VAMPYR-II [21], which allowed more accurate measurements but was operated 1987-88 only, are compared to values of VAMPYR-I: Cs137 release rates of VAMPYR-II [21] are up to a factor of 3 to 30 higher than those of VAMPYR-I, although even VAMPYR-II is known to underestimate release rates. The final filter of VAMPYR-II in downflow direction, which contained Cs, was not evaluated [41]. Further, VAMPYR-II sampled gas of average hot gas temperature, which is not conservative because of the exponential temperature dependence of release rates.

Another strong indication for an underestimation of release rates by VAMPYR-I is the low metallic fission product deposition per coolant pass, calculated from VAMPYR-I and cold gas filter [5], in comparison with model calculations. Further, some coarse post operation examinations in course of AVR dismantling came to the conclusion that in 2002 about $310^{13}$ $\mathrm{Bq}$ of Cs-137 were present in the primary circuit [34]. Some loose dust containing metallic fission products was however already removed at this time and is not included in that balance. This is equivalent to an underestimation of Cs-release rates by about a factor of 3 to 4 in [1a]. The uncertainty range of accumulated Cs-137 and Sr-90 release expected on basis of these considerations is shown in fig. 2, too. Additional measurements on AVR contamination, which are performed in course of dismantling, have to be included into these estimations. Recent still unpublished data of the AVR-contamination as assumed for the approval of the dismantling [46] are in the same range as estimated in this paper, i.e. remarkably higher than in [1a].

Considering AVR volume flow and underestimation of release rates by VAMPYR-I the core release rates $\mathrm{R}$ of Cs-137 are calculated from coolant activities A of fig. 3 as follows:

$$
R[B q / s]=500 \cdot A\left[B q / m^{3} \text { STP }\right]
$$

The core release rate of $\mathrm{Sr}-90$ for a core composition as in the time period 1974-78 at a hot gas temperature of $950^{\circ} \mathrm{C}$ was calculated to $20 \mathrm{GBq} / \mathrm{y}$ by standard diffusion models/data [24], i.e. several orders of magnitude smaller than observed. Unfortunately, the enhanced release of metallic fission products was detected with several months of delay only, when already a major contamination had happened: This was, because a fast release measurement of metallic fission products does not exist. In addition -in contrast to expectations- no conspicuous release of easily detectable noble gases by fuel failure accompanied the release of metallic fission products. Further, calculations of the total primary 
contamination on basis of VAMPYR-I data [23] were erroneous until 1988 and underestimated the Cs-137 contamination compared even to data of [1a] in fig. 2 and 4 by a factor of 5 . Accordingly, during reactor operation the contamination was not taken as serious as it was and no consequences were drawn.

The release mechanism of all metallic fission products will be discussed in detail in chapter 3.3. In rating the releases of metallic fission products in comparison with future power reactors it has to be noted, that AVR-operation at hot gas temperatures $>900^{\circ} \mathrm{C}$, when most of the releases occurred, sums up to only 4 years.

Graphite dust of the AVR primary circuit contained also small but radiotoxic relevant quantities of actinides (Pu-241, Am-241), mainly caused by pebble rupture and destruction of coated particles. Because of larger compressive loads in advanced HTRs [5] this problem has to be examined more detailed. Here, unexploited THTR experience should be considered, too [10]: The large fuel element rupture in THTR can be attributed to a major part to rod movement in the core, but other compressive loads may have contributed, too.

An important consequence of the large primary circuit contamination, which is mainly found in loose and adhesively bonded dust, is the amplification of AVR dismantling costs (see chapter 1). Another consequence was discovered 1994: In course of a slow accidental steam/water ingress of $2.75 \cdot 104 \mathrm{~kg}$ in 1978 [3], about $1500 \mathrm{GBq}$ of the accumulated Sr-90 was washed out, together with $105 \mathrm{GBq}$ of $\mathrm{H}-3$. The reason why $\mathrm{Cs}-137$ was washed out in a smaller fraction than $\mathrm{Sr}-90$ is not known, but may be due to smaller Cs-concentrations in regions, affected by liquid water. Some of the water contaminated with $\mathrm{Sr}-90$ and H-3 leaked by human error into the reactor grounding, from where it reached the surrounding soil [18,53]. The soil contamination on the AVR site ranges from 1 to $1200 \mathrm{~Bq} \mathrm{Sr-90/kg} \mathrm{[53].} \mathrm{A}$ decontamination will take place after removal of the reactor. Because the steam generator leak was small, this accident was not a design basis accident: Core temperatures were already low when large water amounts were present and thus the extent of the graphite/steam reaction remained limited.

\subsection{Influence of unintentional temperatures on fission product release}

Assuming that maximum temperatures measured in 1986-87 are not higher than in 1974-76 it becomes clear, that the enhanced fission product release is correlated to overheating: Hot gas temperatures of $850^{\circ} \mathrm{C}$ led to release rates by 2 - 4 orders of magnitude smaller (fig. 2). This conclusion is supported by measurements of fission product release in the US-Peach Bottom HTR with well known, continuously measured core temperatures (operated 1967 - 74 with block type fuel, representing a similar fuel development stage in its core 2 as AVR 197078): Particularly the Sr release was by several orders of magnitude smaller than in AVR [7,22], but also Cs-release in Peach Bottom was substantially lower than in AVR. 
The fraction of defective coated particles in Peach Bottom core 2 was even at $3.4 \%$ [33] due to a high density of particles in the matrix. Average coated particle defect fractions in AVR varied with time but were smaller. In the period 1974 - 76 a limited increase of iodine and of noble gas release rates was observed in AVR [1a]. This enhanced release cannot be attributed to intact particles (see chapter 3.3). The observed increase is however partly due to accelerated diffusion out of defective particles by higher temperature. An increase of the average coated particle failure fraction by a factor of 2 to 4 is estimated from that release data, which obviously cannot explain the release enhancement of metallic fission products. This underlines that a strong correlation between coated particle defect fraction and release of metallic fission products does not necessarily exist (see also chapter 3.4).

For completion it has to be noted, that the average AVR hot gas temperature was in 1976 due to a calculation error for several months even at about $990^{\circ} \mathrm{C}$, see fig. 2, which accelerated release of metallic fission products.

\subsection{Release mechanisms of metallic fission products}

We have to distinguish 3 sources of fission products: Intact coated particles, particles with defective coatings and the uranium contamination of the graphite resulting from manufacturing. Progress of fuel element technology (e.g. SiC coating) diminished the fraction of uranium in defective particles and uranium contamination during AVR operation from $10^{-2}$ to $10^{-4}$. Non metals are virtually completely retained by intact particle coatings, i.e. the fuel element acts as an efficient barrier and a partial release occurs from defective particles and uranium contamination only. Metallic fission products however diffuse even through intact coatings and the latter become penetrable at high temperatures [26]. For that, the fuel element is a sufficient barrier for metallic fission products only up to a certain temperature limit, which depends on mobility of the metal and on the irradiation time. For temperatures below these limits, i.e. negligible release rates from intact coated particles, the release of Cs and $\mathrm{Ag}$ is caused by the small level of uranium contamination and defective coated particles. Diffusion through barriers is characterized by 2 parameters: The breakthrough time $t_{B}$ reflects the initial diffusion phase before steady state diffusion is reached and characterizes the maximum retention time of a barrier:

$$
t_{B}=I^{2} /(6 D)
$$

with $I=$ coating thickness, $D=$ diffusion coefficient of fission product in coating. Steady state diffusion rates in coatings are proportional to D/l. Because of the temperature dependence of diffusion in solids the breakthrough time decreases, and the stationary diffusion rate increases with increasing temperature. Besides temperatures there are other parameters accelerating diffusion rates in HTR fuel, as burn-up and neutron fluence. However, these parameters are not fully understood. Fig. 4 contains a scheme of break through. 


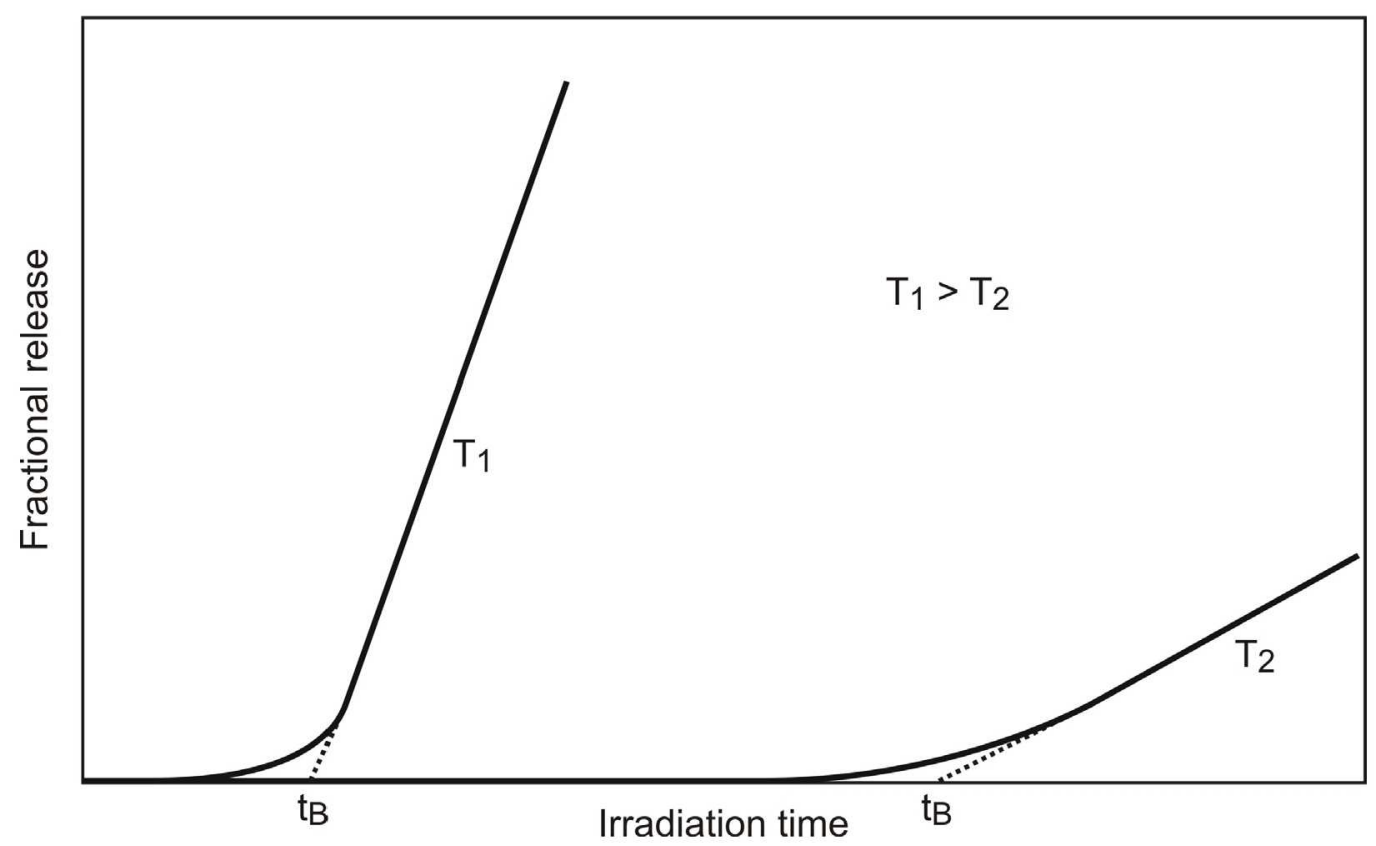

Fig. 4: Schematic diagram of diffusive break through out of an infinite reservoir through a diffusion barrier for 2 different temperatures (tB $=$ break through time)

The following table III contains the breakthrough time at $1250^{\circ} \mathrm{C}$ (maximum coated particle design temperature) for different barrier components of HTR fuel pebbles. Buffer layer and LTI-PyC are not considered, because their retention capability is small compared to other barriers (except for the unique LTI-BISO coating in fuel type GLE-1, see chapter 3.4). The data scatter of about one order of magnitude reflects uncertainties of diffusion coefficients $[21,27]$. The breakthrough time can be only approximately used as an indicator for the start of a significant fission product release: Because of the continuous increase of long lived fission product concentrations in normal operation tB represents a lower limit for break through, if within of the break through time tB the fission product concentration in the kernel sufficiently increased. On the other hand, for $t=t B$ already some release has taken place, which depends on the ratio of coating thickness to kernel diameter. This release is for coated particles already at several percent.

\begin{tabular}{|c|c|c|c|}
\hline \multirow{2}{*}{ Nuclide } & \multicolumn{3}{|c|}{ Breakthrough time t $_{\mathbf{B}}$ [d] in } \\
\cline { 2 - 4 } & $\begin{array}{c}\text { HTI-PyC } \\
(85 \mu \mathrm{m}, \mathrm{BISO})\end{array}$ & $\begin{array}{c}\mathrm{SiC} \\
(35 \mu \mathrm{m}, \mathrm{TRISO})\end{array}$ & $\begin{array}{c}\text { A3 matrix graphite } \\
(5 \mathrm{~mm})\end{array}$ \\
\hline Sr-90 & $1-10$ & $10-100$ & $\leq 200$ \\
\hline $\mathrm{Ag}-110 \mathrm{~m}$ & $1-10$ & $10-100$ & $<0.5$ \\
\hline Cs-137 & $1000-10000$ & $50-500$ & 1 \\
\hline
\end{tabular}

Tab. III: $\quad$ Breakthrough time $t_{B}[d]$ for metallic fission products at $1250^{\circ} \mathrm{C}$ in components of HTR fuel pebbles 
Altogether, not only the temperature is a relevant parameter for release estimates of metallic fission products but even more the temperature dose (temperature * time). There is also some influence of burn-up and neutron dose, both accelerating diffusion.

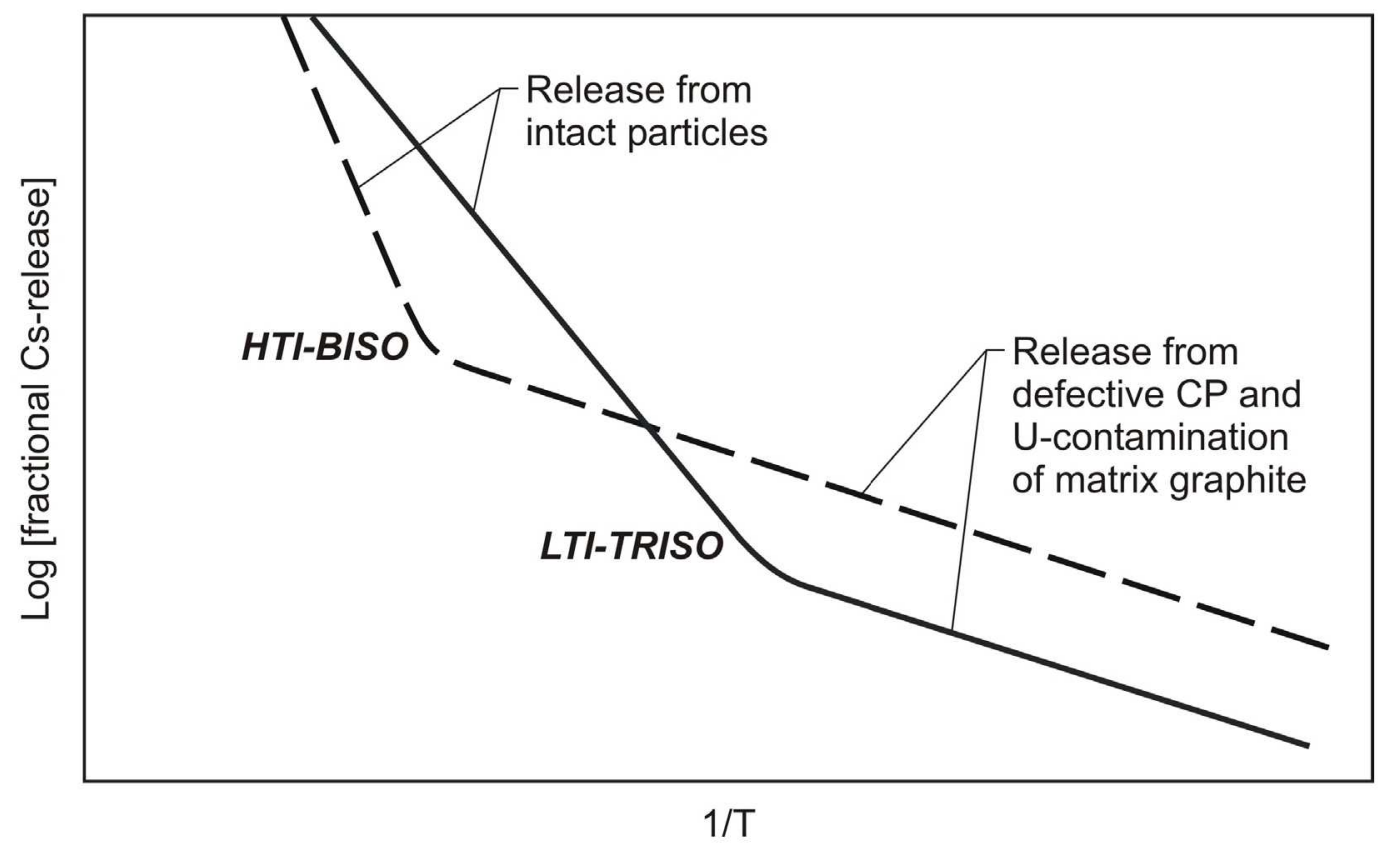

Fig. 5: Schematic comparison of the temperature dependence of Cs-release in former HTI-BISO- and modern LTI-TRISO fuel elements in long term normal operation

Additional diffusion calculations indicate that in oxide kernels the Sr-retention is dominated by interaction with the kernel, which has to be considered in addition to the data of table III. In contrast the graphite is the dominant $\mathrm{Sr}$ retention barrier for carbide fuel kernels. Chemisorption of metallic fission products in matrix graphite, which is modelled by a partition coefficient at the graphite/gas boundary, also increases the retention for Sr. Table III indicates that for TRISO-fuel breakthrough is possible at $1250^{\circ} \mathrm{C}$ for all nuclides during fuel irradiation time ( 3 to $4 \mathrm{y}$, about $1 / 3$ at high temperatures), but the release rate remains small for $\mathrm{Sr}$ due to retention by the oxide kernel. For HTI-BISO fuel no Cs-breakthrough has to be expected, but Ag-release and in case of carbide kernels also Sr-release is larger compared to TRISO oxide fuel. Accordingly, Cs-retention in intact TRISO coated particles is worse compared to former HTI-BISO fuel. On the other hand, modern TRISO fuel strongly reduces the uranium contamination of graphite and thus the release rates of iodine and noble gases in normal operation. Altogether, modern TRISO fuel represents a compromise and may create greater problems concerning Cs-release at high temperatures. Fig. 5 compares schematically the temperature dependent Cs-release for former BISO and modern TRISO fuel elements in long term normal operation. 
A recent irradiation of 5 modern German fuel elements at high temperatures [37] discovered a worse behaviour than expected. GLE-4 LEU fuel elements representing the highest quality achieved in the German HTR fuel program were used. GLE-4 fuel elements $(1 \mathrm{~g} \mathrm{U}-235,6 \mathrm{~g}$ total heavy metal) were also present in AVR during its final operation. The experiment was undertaken in order to demonstrate the applicability of present HTR fuel for Very High Temperature Reactor (VHTR) applications. Experimental conditions were as follows: Maximum pebble central temperature $1250^{\circ} \mathrm{C}$, average temperatures in the particle containing zone about $1150^{\circ} \mathrm{C}$, pebble surface temperatures $1000-1050^{\circ} \mathrm{C}$, irradiation time about $1 \mathrm{y}$, burn-up $11.1 \%$ fima. It has to be noted that the burn-up target value of $15.4 \%$ fima was not reached. Even though the number of defective particles increased by a factor of about 10 more during irradiation than expected and also a "significant" release of Cs and $\mathrm{Ag}$ out of the fuel elements was observed. The latter remains to be quantified. During this experiment there was by human error a temperature excursion of about $250-300 \mathrm{~K}$ for a short period, which however was not expected to be responsible for the large activity release. Short term temperature excursions in earlier irradiations (FRJ2-K15/3) resulted in an increased noble gas release during the enhanced temperature period only. An ongoing similar experiment with GLE-4 fuel elements at about $150 \mathrm{~K}$ lower temperatures does not show up to now higher noble gas releases than expected. These results underline that even modern HTR fuel is not yet suitable for high temperature applications, and that the maximum design temperature of fuel particles of $1250^{\circ} \mathrm{C}$ for current TRISO fuel is too optimistic and should be reduced by about $100-150 \mathrm{~K}$.

\subsection{Interpretation of AVR release rates after hot gas temperature increase to $950^{\circ} \mathrm{C}$}

Looking on fig. 2 and 4 it becomes obvious, that the temperature increase starting February, 1974 leads with a delay of about 0.5 to $1.5 \mathrm{y}$ to release rates of $\mathrm{Sr}$ and $\mathrm{Cs}$ by about 3 orders of magnitude larger than before. The $\mathrm{Ag}-110 \mathrm{~m}$ release became even almost complete soon after temperature increase and thus its increase is smaller. The delayed start of the release is mainly due to diffusion effects (see chapter 3.3), but a slowly increasing particle failure fraction (GLE-1, see below) has contributed for Cs, too. An AVR fuel element does not remain at constant temperatures, but undergoes temperature cycling down to temperatures of about $300^{\circ} \mathrm{C}$ during its flow through the core. This enlarges diffusion break through times.

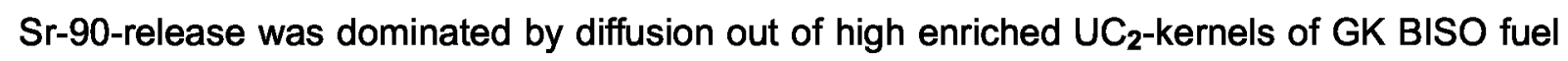
elements: Only one GK-fuel element (of about 25 examined) without release of Eu as indicator for Sr was found after 1975. The contribution of the uranium contamination of the matrix graphite and of defective particles to enhanced Sr-releases remained small, because in BISO-UC ${ }_{2}$-fuel the graphite is the dominating barrier (table III), which is acting also for matrix contamination and defective particles. Further, fission products generated from 
uranium contamination are predominantly located in the interior of crystallites and not on pore surfaces: This leads to an additional retention, which was also observed in AVR. A limited number of first fuel loadings (UCC, T) was 1974 still present in the core. Their behaviour was similar to that of GK. From 1980 improved fuel qualities and altogether lower temperatures led to smaller release rates from core, which are however still on a safety relevant level and will be discussed in chapter 3.5.

For Cs-release the situation is more complex, also because of the pronounced retention capability of HTI-BISO coatings. There was however a small charge of 2400 wrong designed fuel elements (GLE-1: oxide kernel, $1.4 \mathrm{~g} \mathrm{U}-235$ i.e $40 \%$ higher content than in other AVR fuel elements, $20 \mathrm{~g}$ heavy metal, LTI-BISO coating, in AVR core from end of 1973). For the limited number of GLE-1 specimen examined an average coated particle failure fraction of 2 $-4 \%$ was measured, but in one individual fuel element up to about $50 \%$. Due to the high heat power of GLE-1 fuel elements the coated particle temperatures were about $120 \mathrm{~K}$ higher than in other fuel elements, which accelerated particle failure rates. Because of errors in temperature precalculations for GLE-1 these temperatures were discovered not earlier than after some years of GLE-1 presence in AVR. The GLE-1 specific temperature enlargement occurred in addition to general temperature enhancement described in chapter 2. Visual inspections of GLE-1 kernels of a fuel element with high particle failure fraction indicated similarities to kernels, heated up in accident test to $1600^{\circ} \mathrm{C}$. Thus in some GLE-1 fuel elements particle temperatures may have exceeded $1600^{\circ} \mathrm{C}$. Irradiated GLE-1 fuel elements without major particle failure fraction were heated in $\mathrm{FZJ}$ to temperatures of $1500^{\circ} \mathrm{C}$. Up to $1250^{\circ} \mathrm{C}$ GLE-1 behaved normal, but at higher temperatures an increasing number of particle defects was observed, which reached about $25 \%$ at $1500^{\circ} \mathrm{C}$. GLE- 1 fuel was completely removed from core until 1984 before their final burn-up was reached.

A re-estimation discovered that defect particles of GLE-1 fuel elements were not predominantly responsible for the Cs-137, in contrast to earlier assumptions [1a]. The LTIpyrocarbon coating of GLE-1 is the main Cs-barrier in GLE-1. However, it is not as efficient as HTI-pyrocarbon of other BISO fuel elements but comparable to SiC coatings in TRISO particles. Coating failures as high temperatures have obviously accelerated the Cs-release. Cs-release fractions measured for selected GLE-1 fuel elements amount to 2 - 6 \% (burn-up of about $5 \%$ fima), see AVR Quarterly Progress Report III/1982 in [25]. Accordingly, the average Cs release rate of GLE-1 was significantly larger than for other fuel elements. Because of the small number of GLE-1 fuel elements in the core they were however not necessarily the dominating source of $\mathrm{Cs}$. In line with this interpretation even HTI-BISO GK fuel elements with high Cs-release out of the particles of up to $25 \%$ were found, see AVR Quarterly Progress Report I/1983 in [25]. The latter may be taken as an indication of very high temperatures. Considering all uncertainties the contribution of GLE-1 to the overall Cs- 
release $1974-78$ is assumed to be in the range of 10 to $30 \%$. There are major contributions from fuel elements with smaller particle defect fractions (GO: $\leq 1 \%$ ) and from uranium contamination of the matrix graphite, but also from diffusion out of intact coated particles for all types of fuel elements.

For future reactors it is relevant that obviously no credit can be taken from the originally assumed strong correlation between the coating failure rate, which is easily detectable by noble gas release, and the release rate of metallic fission products (see also chapter 3.2). Both are preponderant independent processes. Accordingly, enhanced release of metallic fission products will be detected with some delay only.

\subsection{Dependence of activity release from AVR core on the core composition}

For future reactors it is also relevant to know the behaviour of modern TRISO fuel. For that, we compare fission product releases from core for the period 1974-1978, when predominantly carbide BISO fuel was in the core, with release rates from 1983-1988, when oxide fuel with an increasing content of TRISO particles was used. Irradiation tests of modern fuel elements, usually applied for the proof of a satisfying behaviour in normal operation, are not available for the range of maximum AVR temperatures, but only up to $1250^{\circ} \mathrm{C}$ fuel central temperature (see chapter 3.3).

In [1a] a negligible release was expected for Sr-90 after 1976 due to the better retention in modern oxide kernels compared to carbide kernels as used in first years of AVR. As discussed already in chapter 3.1 this cannot be validated: Eu-154 release rates decrease by about a factor of 20 in AVR after change to oxide fuel. This finding is supported by accelerated irradiation tests of oxide fuel elements at temperatures $\geq 1250^{\circ} \mathrm{C}$ : The irradiation of oxide fuel elements in FRJ2-K3 experiment at surface temperatures of $1400^{\circ} \mathrm{C}$ resulted in a release of even almost $10 \%$ of $\mathrm{Sr}-90$ already within 37 days [11]. At $1300^{\circ} \mathrm{C}$ there was only minor release out of the fuel element in 37 days, but substantial release from particle into graphite occurred. Irradiation experiments at $1250^{\circ} \mathrm{C}$ surface temperature but $104 \mathrm{~d}$ of irradiation (FRJ2-K9/B 3) came to similar results as FRJ2-K3 $\left(1300^{\circ} \mathrm{C}\right)$. The fuel particle temperature was high in FRJ2-K3, which partly explains the large release rate at $1400^{\circ} \mathrm{C}$. Although these fuel elements belong to an early development stage they are still representative for $\mathrm{Sr}$ : The main Sr-retention, oxide kernel and matrix graphite are already present.

There are Eu-154 and even some Sr-90 measurements in the AVR cold gas region (cold gas filter, see fig. 1a), which however show an even smaller dependence of sampled activities on temperature or composition of the AVR core than the VAMPYR-I experiments. This effect is due to the predominantly dust bound status of $\mathrm{Sr}$ and $\mathrm{Cs}$ in the cold gas: Dust is continuously settled and mobilized during operation, which means, that the cold gas filter also samples 
older dust and accordingly integrates to some extent over the prior release history. Also, the higher the mobilization degree the higher is the content of old dust in the filters. Further, the specific dust activity depends on the actual dust production rate. In addition, the sampled amount of dust is influenced by gas flow perturbations during the sampling period. Accordingly, interpretation of activity data measured in the cold gas is subject of large uncertainties and the data are not used here.

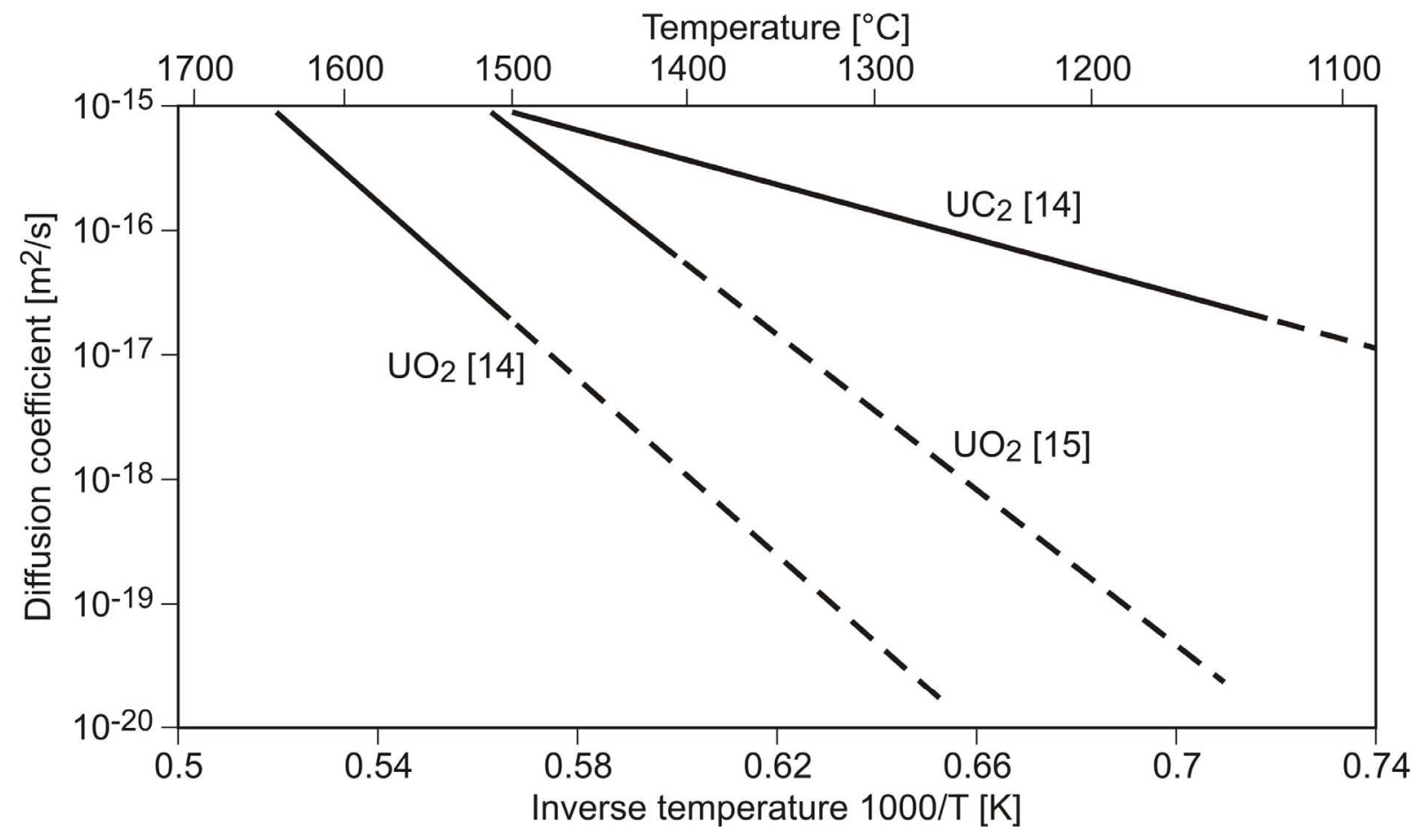

Fig. 6: Measured Sr-diffusion coefficients in $\mathrm{UC}_{2}$ and in $\mathrm{UO}_{2}$

Sr-90 release shows a pronounced temperature dependence in oxide fuel, but a much smaller one in carbide. Measured diffusion coefficients of $\mathrm{Sr}$ in $\mathrm{UO}_{2}$ and $\mathrm{UC}_{2}$ are presented in fig. 6: There are 2 data sets for $\mathrm{UO}_{2}$ which reveal similar temperature dependence, but differ in absolute values by about one order of magnitude. This difference may be due to unequal radiation induced enhancements of diffusion. Comparing the higher $\mathrm{UO}_{2}$ diffusion coefficient with that in $\mathrm{UC}_{2}$ we find, that both are of the same order at $1500^{\circ} \mathrm{C}$, whereas at $1200^{\circ} \mathrm{C}$ the diffusion in $\mathrm{UO}_{2}$ is by a factor of about 500 slower. Taking these values a reduction factor of $20 \pm 10$ for modern oxide fuel is in line with maximum AVR core temperatures of $1300-$ $1400^{\circ} \mathrm{C}$, which correspond to somewhat higher coated particle temperatures. Considering that in carbide fuel the matrix graphite determines the Sr-release rate over a wide range of temperature the behaviour of oxide and carbide fuel converges even more.

Whereas Sr-90 is mainly retained in the oxide kernel and in graphite but less in coatings, the principal diffusion barrier for Cs-137 is the particle coating (SiC in TRISO or even more BISO-HTI pyrocarbon). For Cs-137 a reduction factor of about 8 was estimated by AVR assuming an operation only with improved and modern fuel [1a]. This was calculated on 
basis of the release behaviour of Cs-137 and of Cs-134 depending on the AVR core composition and temperature.

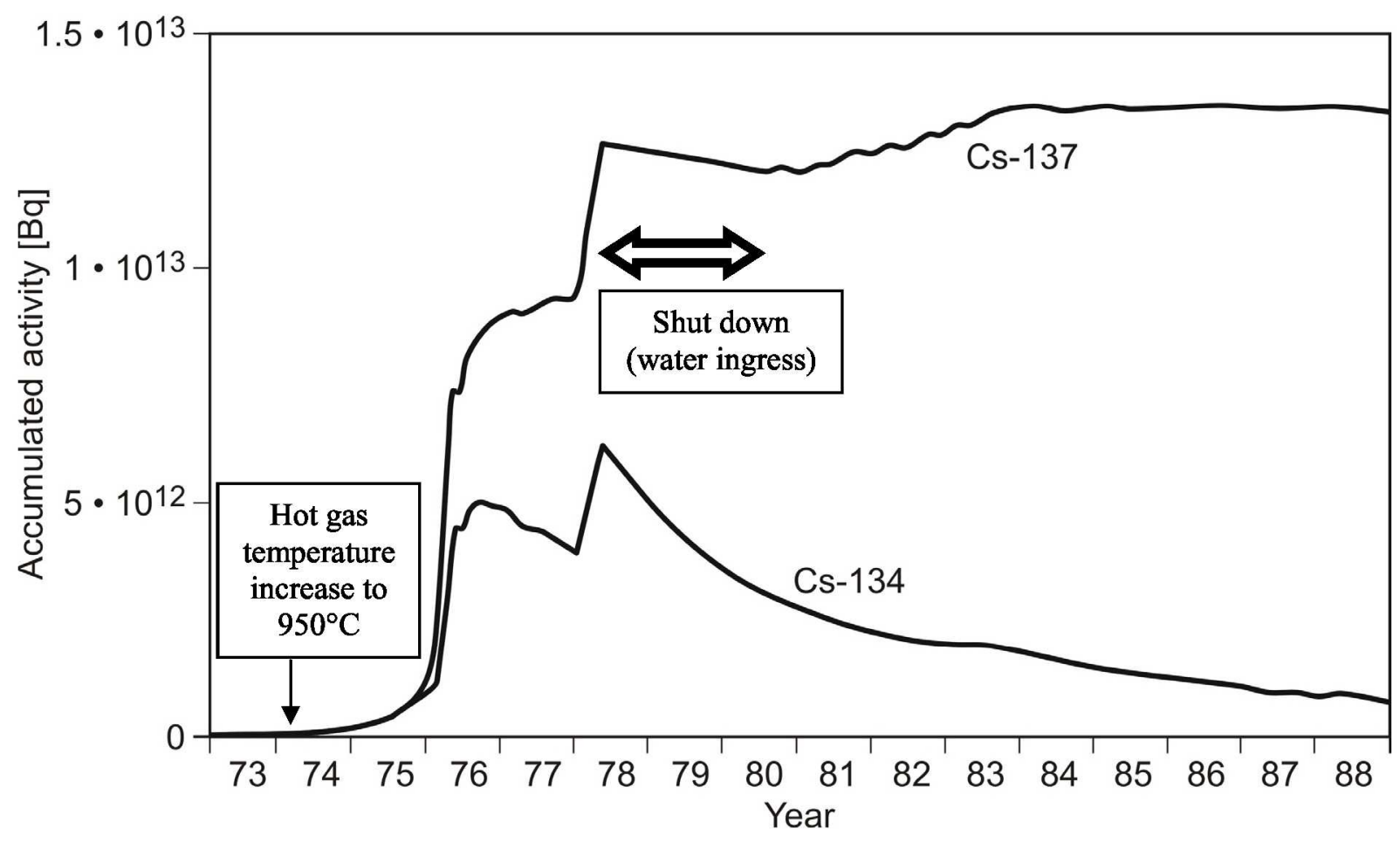

Fig. 7: Accumulated Cs in AVR primary circuit as calculated from VAMPYR-I results [1a]

Fig. 7 contains the VAMPYR-I-data of both Cs-isotopes for the whole operation time 19731988 in a linear scale. Particularly the declination of Cs-134 (t1/2 = 2 y) reveals that during use of improved fuel the Cs-release rate in the AVR dropped between 1975 and 1987 by almost 1 order of magnitude, but remained in a still significant order. In rating of fig. 7 we have to bear in mind that a negligible release rate corresponds to a declination of the accumulated activity, as observed in the shut down period of $1978 / 79$. The fact that measurements for two $\mathrm{Cs}$ isotopes of different halve life exist allows a more reliable estimation of the Cs reduction factor. However, in the period of predominant use of improved fuel in AVR (from 1983) the average temperature was altogether lower than in the period 1973-1978 (see fig. 2 and 3). As outlined in chapter 3.3 the release rate does not depend only on actual temperatures, but on the whole temperature history the fuel element has seen, respectively on the temperature dose (i.e. temperature multiplied by time). In estimation of the reduction factor of $\mathbf{8}$ the latter was not considered, which means, that the true reduction is expected to be somewhat smaller. The accumulated release from 1981 to 1988 amounts to about 30 to $35 \%$ of that in the phase 1973 to 1978 . In comparison of releases in these both operation periods it has to be taken into account that the fuel feeding ratio inner core to outer core was 2.66 in 1972 - 81, but 1 during the other AVR operation. The enlarged feeding ratio into the inner core was set in order to flatten the radial temperature profile [3]. However benign results of this measure were not detected and from 1981 AVR operation occurred again with a feeding ratio of 1 [3]. For that it cannot be excluded that a feeding ratio of 2.66 
has enlarged maximum core temperatures. Another reason for higher maximum core temperatures in the operation time until 1981 may be the large error margin of the fuel burnup measurement in that period. The high Cs-release rate in the first quarter of 1978 (see fig. 3) may be connected to a high moisture level in the coolant, which was already observed several months before of the water ingress of May, 1978.

For periods when GLE-1 fuel elements discussed in chapter 3.4 do not contribute to release rates, an even larger Cs-release of improved TRISO fuel may occur, as comparison of Csrelease rates of 1973 (BISO-fuel) with those of 1987 for similar temperatures indicates (see fig. 3).

The following additional observations underline, that Cs-diffusion out of intact coated particles in AVR was high for improved and modern TRISO-fuel: At first the evaluation of VAMPYR-II (see chapter 3.2), whose Cs-release/birth ration at hot gas temperatures of $930^{\circ} \mathrm{C}$ (1987) was $>10^{-3}$, i.e. significantly larger than the fissile fraction outside of intact coated particles in that period. Further, postexamination of 12 modern GLE-3 fuel elements (TRISO, $1 \mathrm{~g} \mathrm{U}-235,10 \mathrm{~g}$ total heavy metal) irradiated in AVR from mid 1982 revealed for 2 low burn-up fuel elements ( $<3 \%$ fima, $10 \%$ U-235) remarkable Cs diffusion out of coated particles, see AVR Quarterly Progress Report IV/1987 in [25]. No indications for defective particles were found for these fuel elements. Having the altogether lower operation temperatures during GLE-3 operation compared to 1973 to 1978 in mind a fraction of $10 \%$ of fuel elements with release from coated particles is in line with expectations. Finally the recent experimental results on GLE-4 [37] described in chapter 3.3 indicate that the retention capability of modern fuel was overestimated in the past.

Another observation in AVR remains difficult to explain: All fuel elements in AVR except those with high release from intact coated particles are contaminated from outside, i.e. show a significantly enlarged specific fission product activity near to their outer surface $[5,23,56]$, as shown in fig. 8. The conventional interpretation assumes that fission products are recirculated via the coolant circuit into the core and deposited on cold fuel elements in the core bottom. This interpretation conflicts with the fact that AVR cold gas contains only dust borne metallic fission products and that the Cs-137 to Cs-134 ratio in dust is about 4 (198788), as is typical for AVR contamination containing fresh and old contributions together: The activities on outer fuel element surfaces however show a Cs-137 to Cs-134 ratio of about 1 (1987-88), as it is expected for fresh contamination released from fuel elements. Taking into account that the contamination source is located upstream from receiving fuel elements, one explanation to be discussed is a hot region, which releases fission products, somewhere below the top of the active core. Standard calculations for these regions however do not result in high temperatures. The Sr-activity on the fuel element surface of 2 examined modern elements is also higher than in the interior. 


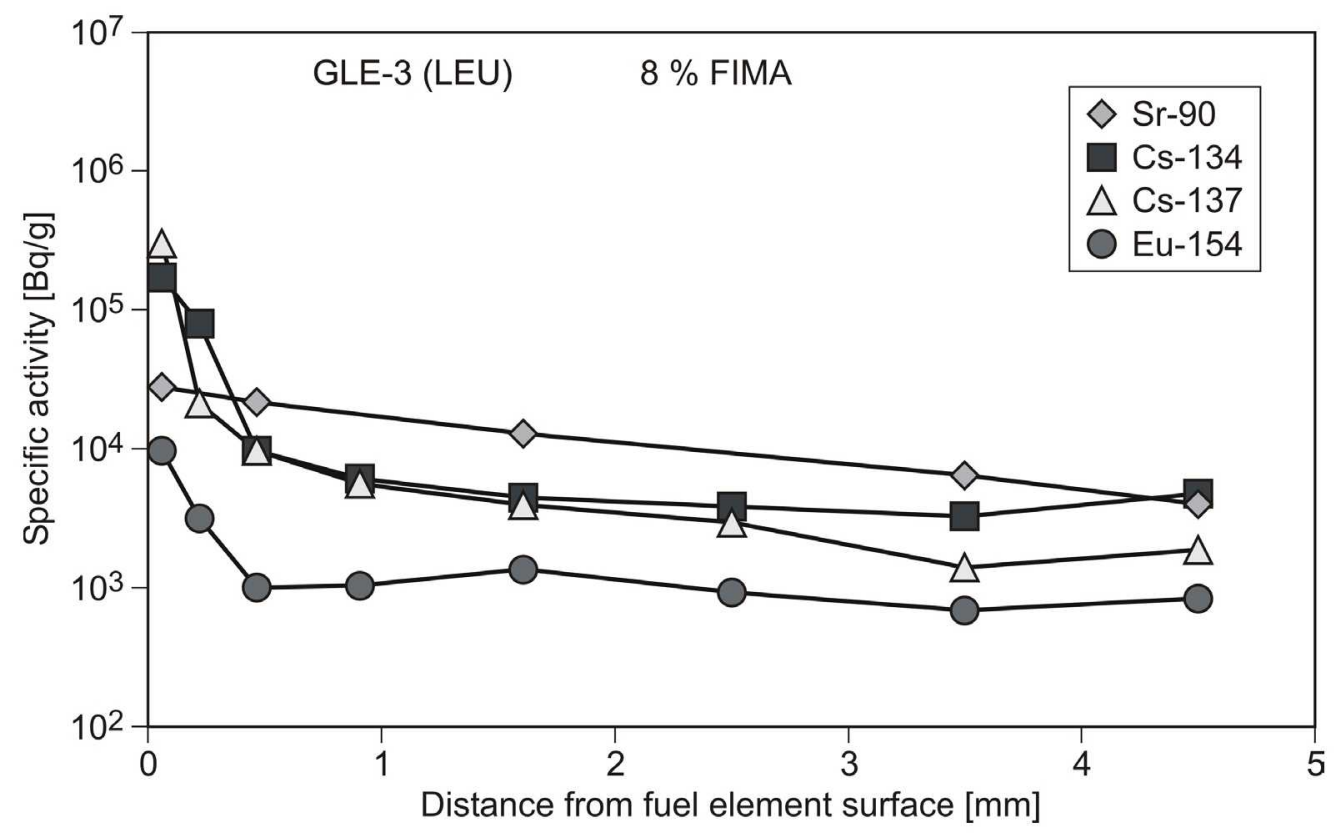

Fig. 8: Concentration profiles of fission products in the fuel free outer zone of a modern fuel element irradiated in AVR 1983-87

For $\mathrm{Ag}-110 \mathrm{~m}$, which is one crucial isotope for gas turbine contamination/maintenance, a by 1 order of magnitude better retention is expected in TRISO fuel, which is however compensated by the larger $\mathrm{Ag}-110 \mathrm{~m}$ inventory in modern low enriched fuel. $\mathrm{Ag}-110 \mathrm{~m}$ release rates are generally higher than those of other metals. Large $\mathrm{Ag}-110 \mathrm{~m}$ inventories in dust on the steam generator were detected 1986 [1a]. Their comparison with those for Sr-90, which are only about a factor of 15 larger, indicate that $\mathrm{Ag}-110$ values of fig. 2 probably underestimate the total release by about 1 order of magnitude. Because of the very fast diffusion of Ag in HTR fuel elements, MOX fuel with high Pu content is not suitable for HTRs: This is because Pu-containing fuel generates far more Ag.

Accident tests of irradiated fuel elements $[16,17,19]$ revealed a reasonable $\mathrm{Sr}$ and $\mathrm{Cs}$ (but not $\mathrm{Ag}$ ) retention for TRISO oxide fuel in the short term $(50-1000 \mathrm{~h})$ for low and medium burn-up at temperatures up to $1600^{\circ} \mathrm{C}$ : Cs-release for medium burn-up fuel starts after about $40-200 \mathrm{~h}$ and amounts to about $1 \%$ after $1000 \mathrm{~h}$ heating. Fig. 9 contains the Cs-release in heating tests at $1600^{\circ} \mathrm{C}$ for TRISO fuel elements and fuel compacts of different burn-up. Extrapolation to long heating times leads to almost complete Cs-release after about $10000 \mathrm{~h}$ [19]. These results are not in conflict with interpretations of normal operation releases in this paper, because a sufficient retention in accident tests is found only for the short term, i.e. as long as breakthrough of the diffusion front has not yet taken place. Extrapolation of accident tests to normal operation via diffusion coefficients in $\mathrm{SiC}$ revealed that at $1250^{\circ} \mathrm{C}$ a comparable release to $1600^{\circ} \mathrm{C}$ values occurs for about 1 order of magnitude greater heating times, which is coarsely in line with results of table III. Here we have to take into account that 
the diffusion of $\mathrm{Cs}$ in $\mathrm{SiC}$ has shows a far smaller temperature dependence at $<1600^{\circ} \mathrm{C}$ than at $>1600^{\circ} \mathrm{C}[21]$.

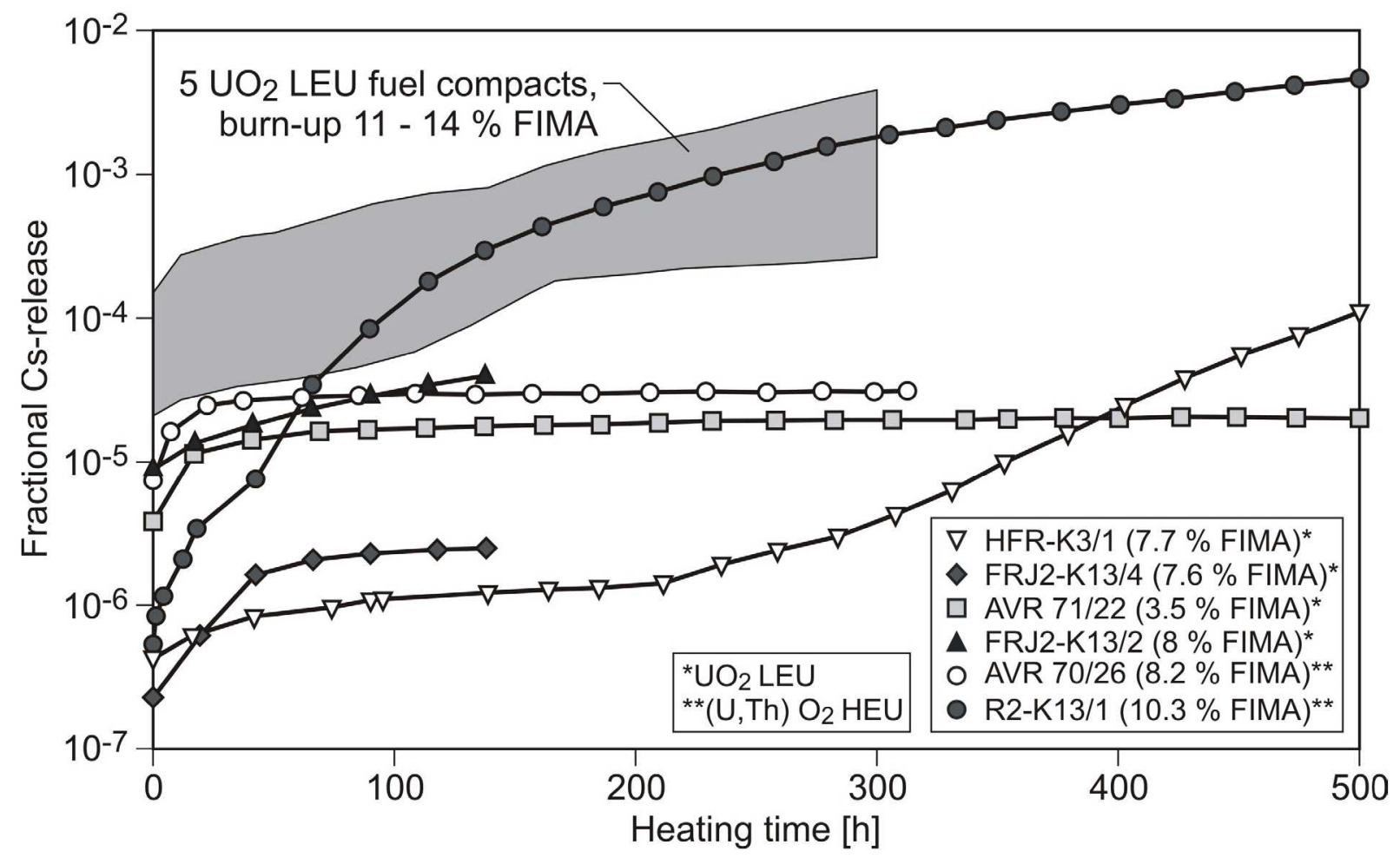

Fig. 9: Cs-release in accident heating tests of TRISO fuel (U-235/total heavy metal $=0.10$ except for AVR 70/26 with 0.17 and R2-K13/1 with 0.09))

Looking on iodine release in core heat-up accidents by diffusion from intact coated particles there is still some uncertainty: it is usually assumed in safety analyses that iodine release from fuel elements happens equivalent to noble gases in normal operation and in core heatup accidents: This means that no diffusion through intact coated particles is taken into account. This assumption is based on two experimental observations:

- At first a similar behaviour of iodine and noble gases in irradiation tests, where release were detected from uncoated uranium only (defective particles and uranium contamination of matrix graphite)

- At second on two short term heating tests (FRJ2-K14, 20 and $43 \mathrm{~h}$ at $1600^{\circ} \mathrm{C}$ ) on reirradiated low burn-up fuel pebbles where iodine release was found to be smaller than the fraction of uncoated uranium

In contrast to noble gas release the iodine release could not be measured in most accident heating test because these heating tests were performed at least several months after end of irradiation, when I-131 and I-133 were no longer present due to decay. Release measurements of long lived $\mathrm{Kr}-85$ in accident heating tests excludes significant noble gas diffusion through intact coatings for time periods of up to $500-1000 \mathrm{~h}$.

However, besides by an equivalent release behaviour of iodine and noble gases these experimental observations can also be explained as follows: The observed similarity of 
iodine and noble gas release in irradiation tests may be pretended by the short halve life of iodine nuclides examined: Their break through time may be much larger than their halve life at these low temperature irradiation tests, but that is - depending on the activation energy of iodine diffusion in coatings - not necessarily true for accident temperatures and prolonged heating times (>100 h). Noble gases and iodine behave chemically very different and thus their diffusion behaviour is expected to be different.

Because of the pronounced radiological relevance of iodine more reliable data of its diffusion behaviour through coatings at accident temperatures are required in order to prove the assumed analogy to noble gases. As long as a reliable proof of the analogy is not available an adequate safety factor in design basis core heat-up accidents should be applied on iodine source tems.

\subsection{Comparison of HTR and LWR fission product behaviour}

There are significant differences between LWR and HTR concerning fuel elements and fission product transport behaviour: Fuel centre temperatures may reach in LWRs values of up to $2500^{\circ} \mathrm{C}$. However on the pellet surface temperatures are $\leq 800^{\circ} \mathrm{C}$, which significantly limits diffusive release. The second barrier in LWRs, the Zircalloy cladding is at temperatures of $320-600^{\circ} \mathrm{C}$ only, which suppresses any diffusive release of metallic fission products via intact claddings. Only fuel elements with defective claddings release fission products. In contrast a diffusion of metallic fission products from intact coat fuel particles cannot be avoided in HTR normal operation because of the higher temperatures and because of the small thickness of the diffusion barriers. Also for that the occasionally claimed compensation of a gas tight containment by the allegedly excellent retention of coated particles (" 5 billion containments in a pebble bed HTR") is far too optimistic.

Another important difference involves fission product behaviour in the coolant circuit. Because of their strong affinity to liquid water, fission products except of noble gases remain in PWRs in the coolant by chemical interaction and physical dissolution, until they are removed by the purification facilities. Typical values of Cs-137 are $1-5 \mathrm{GBq}$ in the coolant of a PWR (high burn-up) and $500-1000 \mathrm{GBq}$ in the resins of the purification facility [36]. The fission product concentrations in metallic components of the primary circuit remain low. This allows an easy handling of fission products released in normal operation. In contrast the affinity of reactive fission products to the coolant $\mathrm{He}$ in HTRs is small and thus these fission products tend to plate out rapidly on primary circuit components and on graphitic dust, as occurred in AVR [1a,5,56]. Already after passing the steam generator more about $90 \%$ of the molecular Cs is plated out $[5,56]$. The equilibrium partition coefficient between plated out Cs and coolant borne molecular $C s$ is in He-cooled systems in the range of $10^{6}-10^{8}$ but almost 0 in LWRs. Accordingly the removal of reactive fission products via a gas clean-up plant is 
not efficient and the fission products accumulate in a not well defined manner in the whole HTR primary circuit during. There were examinations on a fission product filter to be installed in the main hot gas stream of an HTR [38]. However these filters were tested in an AVR bypass for up to 2 months and did not work successful for Cs, but indicated some limited efficiency for Ag [41]. Decontamination of the HTR primary circuit was found to be difficult, also because in hot parts diffusion of fission products into primary circuit components occurs. This fission product accumulation in the primary circuit is a major unresolved disadvantage of HTRs with respect to its safety, maintenance and dismantling/disposal. As long as this HTR problem is not resolved, the requirements on fission product retention of fuel elements have to be far more stringent for HTRs compared to LWRs.

\section{Relevance of AVR experience for future pebble bed reactors}

\subsection{Maximum permissible environmental release in design basis accidents}

What are the implications of temperature uncertainties for future pebble bed HTRs? Enhanced fission product accumulation in the primary circuit during normal operation is a major safety concern, because these activities were found by safety analyses to be main source term contribution in design basis accidents (see [5] and literature cited there), and may even contribute significantly to the risk.

Aggravating, future HTRs are at present not designed with a gas tight containment, as the AVR had. In direct cycle HTRs the activity deposition on the gas turbine, which at present cannot be sufficiently decontaminated, hinders the required hands on maintenance [6]. A gas turbine in a secondary cycle with an intermediate heat exchanger, as discussed for the French ANTARES block reactor project, avoids this problem. However, the efficiency drops and additional components are required. A similar problem exists with the graphite side reflector whose exchange after about 20 y of operation is under discussion for pebble bed HTRs. This exchange is probably required, because graphite tends to expand even at high temperatures if certain neutron doses are exceeded. Further on, maximum temperatures in core heat-up accidents may be enlarged by inadmissible high normal operation temperatures. In order to suppress graphite oxidation with formation of burnable gases in design basis accidents, the normal operation core temperatures in steam and process heat generating HTRs must remain limited.

Assuming a reactor with modern fuel, $400 \mathrm{MWth}$, hot gas temperatures of $900^{\circ} \mathrm{C}$ and core temperature enhancements similar to AVR leads to end of life (32 y full power operation) contaminations at least in the same order as in AVR end of life. This is estimated on basis of the reduction factors evaluated in chapter 3.5. Here we have to note again that AVR was 
operated for only less than $4 \mathrm{y}$ at hot gas temperatures $\geq 900^{\circ} \mathrm{C}$. This means that consequences of contaminations as in AVR have to be carefully considered.

Table IV contains release limits of individual key nuclides into the environment in case of design basis accidents for German licensing conditions. The values given are calculated on basis of the maximum tolerable doses $(50 \mathrm{mSv}$ effective and red bone mark dose, $150 \mathrm{mSv}$ thyroid dose), taking into account the obliged source term - dose calculation ordinance [42]. For a given source term there are only two site specific parameters, which influence the doses at the fence: These are the minimum distance to the fence and the emission height. In case of a common release of several nuclides, the individual exclusion release limits drop. Further on, ALARA holds here and therefore the releases limits must not be reached, if that is reasonably achievable. This table contains equilibrium core inventories of the HTRModule200 as a typical example for a modern design with advanced fuel, too.

\begin{tabular}{|c|c|c|c|c|}
\hline Nuclide & Halve life & $\begin{array}{c}\text { Total core inventory } \\
\text { HTR-Module }\left(200 \mathrm{MW}_{\text {th }}\right) \\
\text { [GBq] }\end{array}$ & $\begin{array}{l}\begin{array}{c}\text { Exclusion } \\
\text { for e } \\
20 \mathrm{~m}\end{array} \\
\end{array}$ & $\begin{array}{l}\text { nit [GBq] } \\
\text { ight } \\
\quad 50 \mathrm{~m}\end{array}$ \\
\hline Sr-90 & $28.8 y$ & $1.37 \cdot 10^{7}$ & 0.4 & 0.6 \\
\hline $\mathrm{Ag}-110 \mathrm{~m}$ & $250 d$ & $1.89 \cdot 10^{5}$ & 270 & 410 \\
\hline $\mathrm{I}-131$ & $8 \mathrm{~d}$ & $2.07 \cdot 10^{8}$ & 5.5 & 10 \\
\hline $\mathrm{Xe}-133$ & $5.3 d$ & $4.44 \cdot 10^{8}$ & $5.7 \cdot 10^{7}$ & $1.1 \cdot 10^{8}$ \\
\hline Cs-137 & $30.1 y$ & $1.67 \cdot 10^{7}$ & 30 & 50 \\
\hline
\end{tabular}

Tab. IV: $\quad$ Calculated exclusion release limits of single nuclides into the environment for design basis accidents (derived from German regulations [42], distance to site fence: $100 \mathrm{~m}$; release duration: $8 \mathrm{~h}$ )

The release limits of table IV are valid for Western Europe with its high population density but for other countries less stringent regulations may be applicable. Release limits as in table IV were in principal applied already to the AVR operation: The maximum permitted coolant activity, which consists almost exclusively of noble gases, was $3.7 \cdot 10^{8} \mathrm{GBq}$ [3], which is near to limit for Xe-133 in table IV. However, no limits were defined for the far more radiotoxic activity which is deposited in the coolant circuit; this was, because it was optimistically assumed that deposited fission products cannot be remobilized in accidents.

The Sr-90 activity accumulated in the primary circuit outside the AVR active core (fig. 2) exceeds German release limits into the environment for design basis accidents by more than 5 orders of magnitude. On the other hand, some safety estimations for modern HTR concepts at hot gas temperatures of $900^{\circ} \mathrm{C}(40 \mathrm{MWth}, 10 \mathrm{y}$ operation) resulted in accumulated Sr-releases of almost 11 orders of magnitude smaller than found in AVR [29]. This discrepancy, which reflects also uncertainties in models and data used, has to be studied and the activities accumulated in future reactors have to be carefully estimated on 
basis of AVR experience in order to avoid an underestimation of the primary circuit contamination.

From data in table IV the maximum tolerable mobile fraction of fission products accumulated in the primary circuit can be estimated from the point of view of protection of the public. In case that unfiltered releases into the environment in design basis accidents have to be assumed (i.e. no gas tight containment), a conservatively estimated mobile fraction of accumulated activities must remain sufficiently below the evaluated exclusion release limits of table IV. In presence of a gas tight containment with filtered release an accumulated mobile activity by at least 2 orders of magnitude larger than exclusion limits of table IV becomes tolerable.

In presence of a gas tight containment other limiting factors may become effective, as there are the above discussed requirements of maintenance and of dismantling: In order to allow hand on maintenance of a direct cycle gas turbine, the total accumulated release of Cs-137 in the primary circuit should not exceed about $500-1000 \mathrm{GBq}$ for Cs-137 or $120-150 \mathrm{GBq}$ for $\mathrm{Ag}-110$ [6], as long as an efficient decontamination of the turbine cannot be performed. Restrictive limits are expected also for a complete exchange of the side reflector.

Metallic fission products occur mainly dust borne in the coolant circuit of pebble bed reactors $[5,56]$. The dust is deposited by gravitation in dead water regions or by adhesive forces on surfaces. The mobilization of deposited activity in pebble bed reactors in course of accidents is not well examined, but some effort is at present spent into that item. There are however data on activity mobilization of specimen from Peach Bottom HTGR. These specimen were similar to AVR and THTR covered with a carbonaceous layer and contained more than $80 \%$ of Cs and Sr released into the coolant circuit of the Peach Bottom HTGR. Blow down tests revealed that at shear forces by a factor of 5 larger than in normal operation between 2 and $25 \%$ of the deposited activity is released within 2 minutes [43]. Later tests on specimen without a carbonaceous layer did not show a mobilization of deposited metallic fission products, but a small release of iodine. For conservative estimations as required in design basis accidents a mobilization degree of $25 \%$ is assumed for depressurization accidents of pebble bed reactors. Japanese estimates result in a release of $15 \%$ of Cs and $40 \%$ of the iodine deposited in the coolant circuit [52]. Formation of carbon dust cannot yet be avoided in current pebble bed reactors but in HTRs with block type fuel.

The following table $\mathrm{V}$ contains maximum tolerable accumulated activities and core release rates (40 y operation) for cases with and without presence of a gas tight containment. ALARA has to be taken into account: Because releases of LWRs remain in design basis accidents far below the limits of table IV, the exclusion release limits of table IV are divided for calculations of the values in table $V$ by a factor of 5 . Similar data were generated by Flowers already 1973 [47], but for a large size block type HTR (3000MWth) with about $500 \mathrm{~m}$ distance to the fence: 
Flowers calculated a maximum tolerable Sr-release fraction of $10^{-7}$ into the environment ${ }^{1}$ (public protection) and a maximum tolerable release fraction of Cs-137 into the coolant circuit of $6 \cdot 10^{-6}$ (maintenance criterion). This agrees reasonably with values of table $V$, having also in mind that current dose factors are larger than those used by Flowers and that the distance to the fence is different.

Typical calculated design values for accumulated primary circuit contaminations of advanced modular HTRs (200 - $400 \mathrm{MWth}$ ) are in the range of 2000 to $20000 \mathrm{GBq}$ Cs-137, depending on hot gas temperatures. Enhanced temperatures as observed in AVR were not yet taken into account. Sr-90-values are calculated to about 2 - 3 orders of magnitude smaller. It becomes obvious that systems without gas tight containment exceed limits for protection of the public by far, even if no temperature uncertainties are considered. For presence of a gas tight containment the limits for protection of the public are met. Deposition of fission products in the containment before the filtered release starts may additionally increase the maximum tolerable activities/releases; accordingly, lower limits are given in table V. However criteria derived from maintenance of a gas turbine, which do not depend on the presence of a gas tight containment, are not met. Nevertheless, a gas-tight containment is required also in future systems, but has to be complemented by other measures, as discussed below.

\begin{tabular}{|c|c|c|c|c|}
\hline Nuclide/criterion & \multicolumn{2}{|c|}{ No containment } & \multicolumn{2}{c|}{ Gas tight containment } \\
\cline { 2 - 5 } & $\begin{array}{c}\text { Max. tolerable } \\
\text { accumulated } \\
\text { activity [GBq] }\end{array}$ & $\begin{array}{c}\text { Max. tolerable } \\
\text { release rate } \\
\text { from core [Bq/s] }\end{array}$ & $\begin{array}{c}\text { Max. tolerable } \\
\text { accumulated } \\
\text { activity [GBq] }\end{array}$ & $\begin{array}{c}\text { Max. tolerable } \\
\text { release rate } \\
\text { from core [Bq/s] }\end{array}$ \\
\hline $\begin{array}{c}\text { Sr-90/ } \\
\text { public protection }\end{array}$ & 0.4 & 0.5 & $\geq 200$ & $\geq 250$ \\
\hline $\begin{array}{c}\text { Cs-137/ } \\
\text { public protection }\end{array}$ & 40 & 50 & $\geq 20000$ & $\geq 25000$ \\
\hline $\begin{array}{c}\text { Cs-137/ } \\
\text { maintenance }\end{array}$ & 1000 & 1200 & 1000 & 1200 \\
\hline
\end{tabular}

Table V: $\quad$ Maximum tolerable accumulated activities in the primary circuit of future HTRs and corresponding maximum tolerable core release rates for cases with and without a gas tight containment. Criteria are protection of the public (see table IV) and requirements of maintenance and disposal.

Considering enhanced temperatures as observed in AVR the following results are obtained: Upscaling of AVR core release rates for Cs-137 as measured in the final AVR operation period 1987-88 in VAMPYR-II [56] to $400 \mathrm{MW}_{\text {th }}$ leads to values of $\geq 35000[\mathrm{~Bq} / \mathrm{s}]$ at $700^{\circ} \mathrm{C}$ hot gas temperature and $\geq 300000[\mathrm{~Bq} / \mathrm{s}]$ at $930^{\circ} \mathrm{C}$ hot gas temperature. These AVR release rates may have been enhanced by presence of fuel, not representing the best achieved

\footnotetext{
${ }^{1}$ Flowers assumes for block type HTRs a release in accidents of $10^{-5}$ of the coolant circuit contamination. With that he calculates a maximum tolerable release fraction of $\mathrm{Sr}$ into the coolant circuit of $10^{-2}$.
} 
quality. For the final AVR operation period thus a reduction factor of 2 to 3 may be applied to measured rates, as long as best estimate values are required. On the other hand in a direct comparison of measured AVR release rates with conservative design values as here, which contain some safety factors, a reduction factor is not adequate.

Sr-90 with its distinctive radiotoxicity shows a more pronounced temperature dependence of release rates than $\mathrm{Cs}$. Thus $\mathrm{Sr}-90$ becomes a major problem when high hot gas temperatures are required and inadmissible high core temperatures as in AVR cannot be excluded: For core temperatures $>1300^{\circ} \mathrm{C}$ Sr-release rates have to be considered as conservative design values, which exceed the even lower limits of table $V$ for the case of a gas tight containment. Altogether, the core temperature uncertainties significantly aggravate existing safety problems.

As long as pebble bed immanent reasons for inadmissible high core temperatures cannot be excluded the following strategies are possible in order to guarantee a safe operation of future pebble bed HTRs: On the one hand side a reduction of demands e.g. reduction of average hot gas temperatures and of average fuel burn-up. On the other hand, major R\&D effort may be spent in order to overcome the existing problems. The latter will be discussed in chapter 5. These strategies complement a gas tight containment. Summing up this means that safe operation of pebble bed reactors can currently not yet be guaranteed at hot gas temperatures suitable for driving of chemical processes like hydrogen generation or coal gasification $\left(950-1000^{\circ} \mathrm{C}\right)$.

The last German pebble bed HTR project, the HTR-Module200 (1988), was designed for average hot gas temperatures of $700^{\circ} \mathrm{C}$, for an U-235 content of $0.55 \mathrm{~g} /$ fuel element, for a maximum fuel burn-up of $9 \%$ fima ( $8 \%$ enriched uranium) and for an average power density of $3 \mathrm{MW} / \mathrm{m}^{3}$. Only for these less challenging conditions the maturity for licensing and construction was seen. However pronounced temperature deviations as observed in AVR were not taken into account. A gas tight containment was not foreseen, because fast depressurizations were excluded in the design philosophy by qualification of large diameter ducts as "vessels", whose failure has not to be assumed in the range of design basis accidents. The latter assumption was meanwhile found to be too optimistic, i.e. fast depressurizations can no longer be omitted as design basis accidents and thus the need for a gas tight containment also for this concept became obvious. Nevertheless, compared to concepts oriented on high-temperature process heat generation the HTR-Module200 with its limited hot gas temperatures, as concepts based on the HTR-Module200 seem to be more realistic, although even here major effort is required before of construction. 


\subsection{Consequences of AVR experience for water ingress accidents}

Another major safety relevant implication of inadmissible high core temperatures lies in the fact that the formation rate of burnable gases in design basis water ingress accidents increases exponentially with temperature: A mixture of $\mathrm{CO}$ and $\mathrm{H}_{2}$ is formed by interaction between steam and graphite. This problem occurs in steam cycle and in process heat generating concepts without an intermediate heat exchanger, but not in present direct cycle ones. A primary circuit depressurization is hardly avoidable in this accident sequence. In order to prevent explosive gas mixtures after depressurization, maximum graphite surface temperatures must not exceed $1100-1200^{\circ} \mathrm{C}[2,4]$, depending on the core temperature distribution. This corresponds to maximum tolerable hot gas temperatures of $<750^{\circ} \mathrm{C}$, if maximum core temperatures of $250 \mathrm{~K}$ higher than calculated with standard methods and as occurring in AVR are assumed. The presence of burnable graphite dust in pebble bed reactors may worsen the situation [5,56]. An enlarged fission product release into the primary circuit followed by water ingress, remobilization of the accumulated activity, depressurization and destruction of last barriers by a gas explosion cannot be accepted as a potential scenario for a design basis accident. Moreover, such accidents are expected to proceed fast, i.e. within of $10-20 \mathrm{~min}[2,4]$. Accordingly, emergency measures become difficult to perform. The prevention of these accidents may require major design changes as reduction of temperatures or an explosion proven or inertized containment.

Hot gas streams as observed in AVR may lead to overheating of parts of the steam generator or of other metallic components which may increase their failure rate. It remains to be examined, whether the slow AVR water ingress of 1978 was caused by such hot gas streams: Temperatures in gas streams below the steam generator of up to $1100^{\circ} \mathrm{C}$ were measured in 1985 [40] but long term stability of AVR metal components was limited to about $850^{\circ} \mathrm{C}$. A sufficient cool down of hot gas streams e.g. by mixing with bypass flows, as originally assumed in AVR design, did not occur.

Another lesson to be learned from AVR water ingress of 1978 belongs to reactivity effects: By human error, the water ingress was not taken sufficiently serious and the reactor was operated at low power for several days in order to dry the primary circuit [3]. The blowers touched the level of liquid water accumulated at the vessel bottom and mixed water droplets to the coolant. In a later stage, when blowers were stopped but the reactor was still in operation, liquid water run out of the steam generator leak into the core. As exhibited later, a fraction of about $3 \%$ of liquid water in the void volume of a pebble bed may lead to a positive void coefficient of reactivity $[28,55]$. These conditions were however not reached in the AVR water ingress accident. In order to exclude such potential reactivity problems future concepts must not foresee steam generators on top of the core. 


\subsection{Consequences of AVR experience for core heat-up accidents}

The influence of inadmissible high core temperatures in normal operation on core heat-up accidents depends on the temperature distribution: Hot spots are evened out during core heat-up, but larger regions of high temperatures may increase the maximum accident temperature beyond tolerable values. A gas tight containment is expected to solve this problem. An active emergency cooling safety system, not yet foreseen in future reactors, is required additionally, if high fuel burn-up is intended or core temperatures in core heat-up accidents $>1800^{\circ} \mathrm{C}$ have to be considered.

\section{Conclusion}

The following major problems of pebble bed HTRs were identified during a re-evaluation of the safety behaviour of the AVR operation:

- Inadmissible high core temperatures, which heavily accelerated the activity release from fuel elements into the coolant circuit, and whose reasons are not yet understood

- An insufficient retention capability of present TRISO fuel elements for metallic fission products particularly in high temperature, long term normal operation as required for process heat applications.

- Safety, maintenance and disintegration problems due to the uncontrolled accumulation of metallic fission products all over the primary circuit. Fission products are present in the circuit to a large part in a mobile form.

Major effort is needed in order to resolve the above listed open safety problems. In any case, a gas tight containment, as included in almost all other modern reactor systems, has to be foreseen for future HTRs. The containment should be explosion proven or inertized in order to prevent from potential dust or burnable gas explosions in accidents. However, a gas tight containment will not sufficiently eliminate all problems listed: Thus pebble bed HTRs require additional safety related R\&D effort and updating of safety analyses before of construction. This includes a careful examination of AVR and THTR experience. In detail the following tasks remain to be examined. This list takes also the results of the NRC evaluation of pebble bed reactors into account $[9,39,52]$ :

- Development and testing of a new fuel element sufficiently retaining metallic fission products $\mathrm{Ag}$ and $\mathrm{Cs}$ in long term normal operation. For HTR application in process heat generation or for high burn-up fuel an improvement of retention of non metallic fission products and of $\mathrm{Sr}$ is required, too. The need for a new fuel element for process heat applications is seen elsewhere too [48]. Screening tests of alternative coatings revealed for $\mathrm{ZrC}$ a better $\mathrm{Cs}$ retention, which is however accompanied by a worse retention for $\mathrm{Ru}$ and $\mathrm{Pd}$, and by a smaller oxidation stability [48]. Accordingly straightforward solutions for a sufficiently retaining fuel element are not yet available. 
Combined $\mathrm{ZrC} / \mathrm{SiC}$ coatings are discussed in [48]. The complete development and testing of a new HTR fuel element may require at least as much as 10 years of intense R\&D.

- Development of a reliable method for quality control of fuel elements. At present, there is no straightforward quality control method for fabricated fuel pebbles available, except of long term irradiation of representative fuel elements of a production charge at normal operation temperatures with subsequent heat up test, which is however too expensive. The quality control method has to cover requirements of normal operation and of design basis accidents.

- Experiments on iodine release from irradiated fuel elements under temperatures of core heat-up accidents. As outlined in chapter 3.6 this is required as proof of the assumed analogy between release behaviour of noble gases and of iodine.

- Full understanding and reliable modelling of the core temperature behaviour, of related temperature problems observed in AVR (power asymmetry, hot gas currents) and of pebble bed mechanics including pebble rupture particularly at extended core heights

- Development of a fast and reliable local measurement method (direct or indirect) of safety relevant parameters in the pebble bed core (e.g. temperatures). Looking on the diverse potential reasons for inadmissible high temperatures in pebble bed reactors, a fast temperature measurement system for the pebble bed is essential. Because of the continuous movement of pebble beds with potential change of configurations those temperature measurements are more important than in conventional static reactors. This is however not only relevant for normal operation but also for the core heat-up event: The progress of this design basis accident cannot be reasonably monitored without knowledge about temperatures in the active core. Because of a temperature drop in pebble beds near to walls, which is caused by elevated porosities inducing higher flow rates, measurements in reflectors are not sufficient: This teaches also experience with thermocouples in AVR reflector noses (see fig. 1c), which did not detect unexpected high temperatures.

- Full understanding of fission product transport behaviour in the primary circuit (e.g. abrasive graphite dust formation and mobilization, including dust interaction with fission products). This includes measures to avoid the current uncontrollable activity accumulation in the circuit over the whole operation time

- Development of a fast detection system for metallic fission product release from core: This system has to be installed at the core exit and should in contrast to former systems not require a reactor shut down for removal of the plate out section. 
- Development of high temperature materials for process heat specific components of HTRs. Respective generic work has already been started. For HTR application a long term high-temperature stability in an irradiation environment is required, which is difficult to achieve with Ni-containing alloys. Further on formation of Co-60, which is distributed over the whole coolant circuit, was observed in AVR and THTR, which hinders maintenance work. For that Co-alloys have to be avoided, too.

- Studies on HTR specific dismantling and disposal items: Due to the large volume of the HTR core containing mainly gas cooled reactor specific waste major challenges on disposal occur. Also from other graphite moderated reactors about $2.5 \cdot 10^{8} \mathrm{~kg}$ of irradiated graphite exist worldwide, which cannot yet be disposed. This graphite contains besides of fission products remarkable activities of long lived C-14, whose efficient separation from the graphite is not yet possible. It has to be discussed, whether the construction of future graphite moderated reactors is responsible, as long as the graphite specific disposal problems are not resolved. R\&D to this HTR disposal problem has been initiated.

Other open problems of pebble bed reactors are discussed in $[5,9,39,52,56]$. Before initiation of the above listed comprehensive R\&D a feasibility study including an estimate of the required $R \& D$ effort is advisable in order to quantify the economical risk of this development. A representative experimental reactor, which is sufficiently equipped with instruments also for in-core measurements, is required for a reliable examination of the open questions. A large number of the open problems cannot be sufficiently studied in out-of pile experiments. This experimental reactor should also allow for detection of the flow pattern of individual pebbles, as of variation of local bed porosities and of dust formation rates. In addition the improvement of the nuclear, thermohydraulic, pebble bed mechanics and fission product release model used in design and licensing of the pebble bed HTR is necessary in order to meet the current international standards. Such model improvements were meanwhile started at PBMR in South Africa.

Concerning beyond design basis accidents there are still unresolved questions connected to a massive air ingress with graphite burning, which may lead to massive fission product releases from the reactor $[45,52]$. Such an air ingress accident was selected as basis for the emergency planning of the AVR. However, priority has to be given to the solution of problems related to safety problems of normal operation and of design basis accidents.

With respect to future very high temperature reactor (VHTR)-concepts as discussed in Generation IV it is advisable to perform a comparative study of pebble bed reactors with block type fuel HTRs, which do not show most of the problems discussed before. More general a comparative probabilistic safety assessment considering Generation III LWRs and pebble bed reactors is required: Development of Generation III LWRs led to major safety 
improvements. In contrast the improved knowledge to safety of pebble bed HTRs since 1990 leads to the conclusion that former comprehensive safety assessments were too optimistic: As outlined above there exist unresolved safety problems in pebble bed reactors for design basis accidents, as for beyond design basis accidents like severe air ingress with graphite burning. Previously a superior safety behaviour of pebble bed reactors was claimed compared to other nuclear systems including an allegedly catastrophe free design. According to the above presents arguments there are doubts, whether this depicts reality.

\section{Acknowledgement}

The author thanks Donald Carlson (NRC) for triggering this study, as Andreas Schaffrath (TueV Nord), Werner Katscher (former FZJ), Klaus Bongardt, Johannes Mertens, both FZJ, and the late Heinz Werner (former FZJ) for valuable discussions to this paper.

Further the author thanks Sigrid Reiche-Begemann (FZJ) for doing the graphics work. 


\section{References}

[1] „AVR - Experimental HTR”; VDI-Verlag Düsseldorf (1990), ISBN 3-18-401015-5. [1a] subchapter 5.2: C.B. von der Decken, U.Wawrzik, „Dust and activity behaviour“ p. 259-75. [1b] subchapter 2.3: N.Kirch, G.Ivens, „Results of AVR-experiments”, p. 90-105. [1c] subchapter 3.3: C.B. von der Decken, G.Lange, „Pebble bed mechanics” p. 154-9

[2] R.Wischnewski, „Untersuchungen zur Wassergasbildung bei Störfällen an HTRReaktoren am Beispiel einer geplanten Heißgastemperaturerhöhung auf $950^{\circ} \mathrm{C}$ am AVRReaktor" AVR-report and PhD Thesis, Aachen (1974)

[3] E.Ziermann, G.Ivens, „Abschlussbericht über den Leistungsbetrieb des AVRVersuchskernkraftwerks.“, Jül-3448 (1997)

[4] U.Wawrzik, "Numerische Simulation des Anlagenverhaltens eines Hochtemperaturreaktors bei Wassereinbruchstörfällen am Beispiel des AVR”, Jül-1908 (1984)

[5] R.Moormann, „AVR experiments related to fission product transport", Proc. HTR2006, Paper F00000042: http://www.htr2006.co.za/index actual.php?site action=downloads

[6] Y.Muto, S.Ishiyama, S.Shiozawa, „Study of Fission Product Release, Plate-out and Maintenance in Helium Turbomachinery", in IAEA-TECDOC 1238 (2001)

[7] D.L.Hanson, N.L.Baldwin, D.E.Strong, „Fission Product Behaviour in the Peach Bottom and Fort St. Vrain HTGRs", IWGGCR-2 (1980) pp. 49-54

[8] M.N.Ramadan, „Messung der Austrittskühlgastemperaturen und des Kugelfliessverhaltens im fliessenden Core eines Kugelhaufenreaktors mittels neu entwickeltem MessSystem“, Jül-1044 (1974)

[9] D.Carlson, R.Lee, F.Odar, „Modeling issues for HTGR designs“, Proceedings of the 2002 Nuclear Safety Research Conference, Washington DC, October 28-30, 2002, NUREG/CP. 0180 (2003), p.49-58

[10] I.Kalinowski, W.Wachholz, „THTR-Betriebserfahrungen aus sicherheitstechnischer Sicht“, Proc. Fachsitzung 'Stand der HTR-Sicherheitsforschung', Jahrestagung Kerntechnik '89 (1989), p. 102 ff, ed.: Inforum (Bonn)

[11] E.Groos, G.Mielken, R.Duwe, A.Müller, M.Will, „Fission product release from coated particles embedded in spherical fuel elements for High-Temperature Reactors“. Nucl. Techn. 35 (1977) 509-15

[12] T.Grotkamp, „Aufbau eines dreidimensionalen Simulationsverfahrens zur corephysikalischen Beschreibung von Kugelhaufenreaktoren mit Mehrfachdurchlauf am Beispiel des AVR“, Juel-1888 (1984)

[13] K.Krüger, A.Bergerfurth, S.Burger, P.Pohl, M.Wimmers, J.C.Cleveland, „Preparation, conduct and experimental results of the AVR loss-of-coolant accident simulation test". Nucl. Sci. Eng. 107 (1991) 99

[14] B.F.Myers, W.E.Bell, „Strontium transport data for HTGR systems”, GA-A-13168; GALTR-16 (1974) 
[15] P.E.Brown, R.L.Faircloth, „Metal Fission Product Behaviour in High Temperature Reactors $\mathrm{UO}_{2}$ Coated Fuel Particles", Journal of Nuclear Materials 59 (1976) 29-41

[16] W.Schenk, D.Pitzer, H.Nabielek, „Spaltproduktfreisetzungsverlauf von Kugelbrennelementen bei Störfalltemperaturen“, Jül-2091 (1986)

[17] W.Schenk, R.Gontard, H.Nabielek, „Performance of HTR fuel samples under highirradiation and accident simulation conditions, with emphasis on test capsules HFR-P4 and SL-P1", Jül-3373 (1997)

[18] „The NEA cooperative program on decommissioning - a decade of progress", NEA-6185 (2006) p.43-44

[19] W.Schenk, D.Pitzer, H.Nabielek, „Fission product release profiles from spherical HTR fuel elements at accident temperatures", Jül-2234 (1986)

[20] K.Verfondern, „Numerische Untersuchung der 3-dimensionalen stationären Temperaturund Strömungsverteilung im Core eines Kugelhaufen-Hochtemperaturreaktors", Jül-1826 (1983)

[21] „Fuel performance and fission product behaviour in gas-cooled reactors”, K.Verfondern (ed.), IAEA-Tecdoc 978 (1997)

[22] F.F.Dyer, R.P.Wichner, W.J.Martin, H.J. de Nordwall, „Distribution of radionuclides in the Peach Bottom HTGR primary circuit during core 2 operation”. ORNL-5188 (1977)

[23] R.Hilgedieck, J.Wahl, „Das Verhalten von Spaltprodukten in Brennelementen aus dem AVR-Core“, Jül-Conf-43 (1981), p.77-84

[24] J.Weber, „Einbeziehung der Spaltproduktfreisetzung in die numerische Simulation des AVR-Abbrand-Umwälzgeschehens und Vergleich mit den VAMPYR-Resultaten“. Jül-1570 (1979)

[25] „IRPHE/AVR: Collection of AVR documents by AEN/NEA", CD-ROM NEA-1739/01 (2005) and http://www.nea.fr/abs/html/nea-1739.html (authorization required)

[26] J.L.Kaae, S.A.Sterling, L.Yang, „Improvements in the performance of nuclear fuel particles offered by silicon-alloyed carbon coatings", Nucl. Technology 35 (1977) 536-47

[27] R.Moormann, K.Verfondern, „Methodik umfassender probabilistischer Sicherheitsanalysen für HTR-Anlagenkonzepte. Band III: Spaltproduktfreisetzung.“ Jül-Spez 388/3 (1987)

[28] A.Leber, Ways and means to limit the ingress of water into the core of HTR-Module", Proc. Basic Studies on High-Temperature Engineering, Paris (1999), p.183-98

[29] A.E. van Heek, "N.B.Siccama, P.H.Wakker, "Fission Product Transport in the Primary System of a Pebble Bed High Temperature Reactor with Direct Cycle", in IAEA-TECDOC 1238 (2001)

[30] K.H.Presser, „Die indirekte Messung von Temperaturen mit metallischen Miniaturschmelzkörpern”, Juel-825-RB (1972)

[31] A.Bergerfurth, H.Werner: „Temperaturabschätzungen zur Auslegung von Gastemperaturmesselementen für ein Experiment zur Messung der Kühlgasaustrittstemperaturverteilung“, AVR Technical Note H5-X1 (17.5.1984) 
[32] H.Haque, „AVR-Versuchsprogramm HTA-5: Kühlmittelverluststörfall, Beitrag zum HTAGesamtbericht bzw. Interatom-Abschlussbericht“, Projekt-Nr. 1818-0500-89, Interatom, 30.01.1990 and „AVR-Versuchsprogramm HTA-5: Kühlmittelverluststörfall“, Interatom-Report Nr. 54.07907.5 (23.01.1990)

[33] K.I.Kingrey, „Fuel summary for Peach Bottom Unit 1 HTGR Cores 1 and 2”, Report INEEL/EXT-03-0103 (2003)

[34] H.Sterner, M.T.Cross, A.Rodriguez: "Decommissioning of gas-cooled reactors", Kerntechnik 70 (2005) 59-65

[35] Generation IV Roadmap: Description of Candidate Gas Cooled Reactor Systems Report. Report GIF-016-00 (2002)

[36] K.H.Kwang, K.J.Lee, "Modelling the activity of ${ }^{129} \mathrm{I}$ and ${ }^{137} \mathrm{Cs}$ in the primary coolant and CVSC resin of an operating PWR", J.Nucl.Mat. 350 (2006) 153-62

[37] M.A.Fütterer et al.: „Results of AVR fuel pebble irradiation at increased temperature and burn-up in the HFR Petten", Nucl.Eng.Des. (2008), doi:10.10106/j.nucengdes.2008.02.017, in press

[38] S.Förster, N.Iniotakis, P.Quell, „Filter for fission products from hot reactor cooling gas”, Patents DE2937209 (1981) and US4362695 (1982)

[39] NRC documents: „Request for Additional Information on Analytical Codes and Software Control; Core Design and Heat Removal and Operational Modes and States for Pebble Bed Modular Reactor”, „Request for Additional Information on Pebble Bed Modular Reactor Nuclear Fuel; Fuel Fabrication Quality Control Measures and Performance Monitoring Plans; and PBMR Fuel Qualification Test Program" in www.nrc.gov/reactors/new-licensing/designcert/pre-app-review/2002.html, and: Official Transcript of Proceedings of the NRC www.nrc.gov/reading-rm/doc-collections/acrs/tr/fullcommittee/2002/rs071102.pdf and www.nrc.gov/reading-rm/doc-collections/acrs/tr/subcommittee/2002/ar070802.pdf

[40] H.Brixy, J.Oehmen, „Temperaturmessung mit kombinierten ThermoelementRauschthermometern im Deckenreflektor des AVR-Reaktors“, KFA-IRE Technical Note (24.04.1985)

[41] R.Moormann, „Source term estimation for small sized HTRs“, Jül-2669 (1992)

[42] Störfallberechnungsgrundlagen für die Leitlinien des BMI zur Beurteilung der Auslegung von Kernkraftwerken mit DWR gemäß $§ 28$ Abs. 3 StrISchV, Bundesanzeiger Nr. 245a, 31.12.1983

[43] J.J.Abassin, R.J.Blanchard, J.Gentil, „In-pile loop COMEDIE“, IWGGCR/2 p.8-18 (1980), and: R.J.Blanchard, „In-pile loop COMEDIE“, IWGGCR/13, p. 57-73 (1985)

[44] K.Kugeler, P.Phlippen, M.Kugeler, H.Hohn, „Overview of High Temperature Reactor Engineering and Research“, in: Basic Studies in the Field of High-temperature Engineering, ISBN 92-64-19796-6 (2002) 
[45] R.Moormann, „Phenomenology of Graphite Burning in Massive Air Ingress Accidents”, Proceedings HTR2006, Johannesburg (RSA): Paper F00000032: http://www.htr2006.co.za/index actual.php?site action=downloads [46] „Sicherheitsbericht zum AVR-Zwischenlager", 2nd revision, internal AVR report (2008) [47] R.H.Flowers, „Fission product control in the HTR”, Proc. International Conference on Nuclear Fuel Performance; 15 Oct 1973; London (UK); paper 23

[48] J.M.Kendall, R.E.Bullock, „Advanced coated particle fuel options”, Proc. HTR2004, $2^{\text {nd }}$ Int. Topical Meeting on HTR Technology, Beijing (China), 22.-24.09.2004, Paper B09

[49] J.Weber, „Berechnung des AVR-Coreinventars für ausgewählte Spaltproduktnuklide“, AVR-Aktennotiz, H5-X1 T1 Web/Schw (08.07.1976)

[50] H.Derz, L.Krings, „Bestimmung der Kühlgastemperaturen im AVR“, Technical Note KFAIRW-TN-77/88 (19.09.1988)

[51] H.Derz, H.Gottaut, P.Pohl, G.Pott, „Experiment HTA-8: The Determination of the Maximum Coolant Temperatures in the AVR Core", Internal Report KFA-HTA-IB-3/90 (26.02.1990)

[52] D.A.Powers, „Trip Report: Travel by D.A. Powers to Attend the High-Temperature GasCooled Reactor Safety and Research Issues Workshop", Rockville, Md., October 10-12, 2001. NRC-ADAMS web server: http://adamswebsearch.nrc.gov/scripts/securelogin.pl Document number ML020450645

[53] MWMI-NRW: „Strahlenschutzbericht 'Sonderausgabe AVR'. Ermittlungen zur Ursache für die Kontamination in den Betonkammern des AVR in Jülich und zur Abklärung der Auswirkungen des kontaminierten Betonkammerwassers auf die Umgebung“". Landtagsvorlage 12/2647 (27.02.2001)

www.landtag.nrw.de/portal/WWW/dokumentenarchiv/Dokument/MMV12-

2647.pdf?von $=1 \&$ bis $=0$

[54] „Summary of Experiment HTA-8 in the AVR Investigation Programme: The Determination of the Maximum Coolant Temperatures in the AVR Core“, compiled by H.Gottaut. Internal FZJ report (28.02.1990)

[55] A.Leber, „Transport und Abscheidung von Tropfen im Primärkreis des Hochtemperaturreaktors bei Wassereinbruchstörfällen“, Jül-4050 (2003)

[56] R.Moormann, „Fission product transport and source terms in HTRs: Experience from AVR pebble bed reactor", submitted for publication in J.Nucl.Installations (2008) 
Jül-4275

Juni 2008

ISSN 0944-2952 